\title{
Seasonal variation of tropospheric bromine monoxide over the Rann of Kutch salt marsh seen from space
}

\author{
Christoph Hörmann ${ }^{1}$, Holger Sihler ${ }^{1,2}$, Steffen Beirle ${ }^{1}$, Marloes Penning de Vries ${ }^{1}$, Ulrich Platt $^{2}$, and \\ Thomas Wagner ${ }^{1}$ \\ ${ }^{1}$ Max Planck Institute for Chemistry (MPI-C), Mainz, Germany \\ ${ }^{2}$ Institute for Environmental Physics, University of Heidelberg, Heidelberg, Germany \\ Correspondence to: Christoph Hörmann (c.hoermann@ mpic.de)
}

Received: 28 January 2016 - Published in Atmos. Chem. Phys. Discuss.: 15 February 2016

Revised: 23 September 2016 - Accepted: 27 September 2016 - Published: 21 October 2016

\begin{abstract}
The Rann of Kutch (India and Pakistan) is one of the largest salt deserts in the world. Being a so-called "seasonal salt marsh", it is regularly flooded during the Indian summer monsoon. We present 10 years of bromine monoxide (BrO) satellite observations by the Ozone Monitoring Instrument (OMI) over the Great and Little Rann of Kutch. OMI spectra were analysed using Differential Optical Absorption Spectroscopy (DOAS) and revealed recurring high BrO vertical column densities (VCDs) of up to $1.4 \times 10^{14}$ molec cm $^{-2}$ during April/May, but no significantly enhanced column densities during the monsoon season (June-September). In the following winter months, the BrO VCDs are again slightly enhanced while the salty surface dries up. We investigate a possible correlation of enhanced reactive bromine concentrations with different meteorological parameters and find a strong relationship between incident UV radiation and the total $\mathrm{BrO}$ abundance. In contrast, the second Global Ozone Monitoring Instrument (GOME-2) shows about 4 times lower BrO VCDs over the Rann of Kutch than found by OMI and no clear seasonal cycle is observed. One reason for this finding might be the earlier local overpass time of GOME-2 compared to OMI (around 09:30 vs. 13:30 LT), as the ambient conditions significantly differ for both satellite instruments at the time of the measurements. Further possible reasons are discussed and mainly attributed to instrumental issues. OMI additionally confirms the presence of enhanced BrO concentrations over the Dead Sea valley (Israel/Jordan), as suggested by former ground-based observations. The measurements indicate that the Rann of Kutch salt marsh is probably one of the strongest natural point sources of reactive bromine compounds outside the polar regions and is there-
\end{abstract}

fore supposed to have a significant impact on local and regional ozone chemistry.

\section{Introduction}

Reactive halogen species (RHS) are well known to play an important role in atmospheric chemistry of both the troposphere and stratosphere (e.g. Platt and Janssen, 1995; SaizLopez and von Glasow, 2012, and references therein). For almost 30 years, ground-based observations in polar regions, at active volcanoes, within the midlatitude marine boundary layer (MBL) and over salt lakes have indicated the potential of these species to significantly influence the oxidation capacity of the troposphere, possibly on a global scale, via the catalysed depletion of ozone $\left(\mathrm{O}_{3}\right)$. After the so-called ozone depletion events (ODEs) were first observed in the 1980s by local measurements in the Arctic (Oltmans, 1981; Oltmans and Komhyr, 1986; Barrie et al., 1988), especially reactive bromine compounds were identified to be responsible for the ozone destruction. In particular, a strong anti-correlation of the ozone concentration with filterable bromine (Barrie et al., 1988, 1989) was found. In later studies, the involvement of bromine chemistry was directly confirmed by additional measurements of bromine monoxide $(\mathrm{BrO})$ using the Differential Optical Absorption Spectroscopy (DOAS) technique (Platt and Stutz, 2008), with $\mathrm{BrO}$ mixing ratios of up to $17 \mathrm{ppt}$ (Hausmann and Platt, 1994). Subsequent observations showed even higher mixing ratios of up to $40 \mathrm{ppt}$ (e.g. Avallone, 2003; Frieß, 2004; Hönninger et al., 2004b; Pöhler et al., 2010; Peterson et al., 2015, and references therein). In the meantime, an overall picture of the $\mathrm{BrO}$ horizontal 
distribution was obtained by observations from satellite instruments in the late 1990s (Wagner and Platt, 1998; Richter et al., 1998; Chance, 1998). It became clear that the ODEs can be associated with huge $\mathrm{BrO}$ "clouds" of several thousands of square kilometres extent.

During the last 3 decades, $\mathrm{BrO}$ has also extensively been measured in the MBL by ground-based DOAS observations, but the observations revealed relatively low $\mathrm{BrO}$ mixing ratios of 1-10 ppt (e.g. Leser et al., 2003; Saiz-Lopez, 2004; Read et al., 2008; Martin et al., 2009). Volcanic BrO has not only been observed by a large number of ground-based DOAS observations at quiescent degassing volcanoes since the early 2000s (e.g. Bobrowski et al., 2003; Oppenheimer et al., 2006; Bobrowski and Platt, 2007; Boichu et al., 2011; Bobrowski and Giuffrida, 2012; Lübcke et al., 2014) but also by satellite instruments during minor and major volcanic eruptions (Theys et al., 2009a; Rix et al., 2012; Hörmann et al., 2013).

\subsection{BrO observations over salt lakes}

In contrast to $\mathrm{BrO}$ observations in other regions, reports about reactive halogen species observations over salt lakes have only been published infrequently. Following the first ground-based DOAS observations of $\mathrm{BrO}$ over the Dead Sea with peak mixing ratios of $86 \mathrm{ppt}$ by Hebestreit et al. (1999), later studies were able to confirm the results and found even higher mixing ratios with a maximum of $220 \mathrm{ppt}$ (e.g. Matveev et al., 2001; Tas et al., 2005), representing the highest $\mathrm{BrO}$ mixing ratios ever observed in the atmosphere (outside volcanic plumes). The vertical distribution of $\mathrm{BrO}$ above the Dead Sea and the corresponding dynamics were more recently discussed in Holla et al. (2015). Much lower mixing ratios of up to $6 \mathrm{ppt}$ were found over the Great Salt Lake (United States) by Stutz et al. (2002) as well as more than 20 ppt at Salar de Uyuni (Bolivia) by Hönninger et al. (2004a). Further field campaigns were conducted by Holla (2012) in Namibia (Walfish Bay), Botswana (Sua Pan), south Russia (El'Ton and Baskunchak), Mauretania (Sebkha N'Dramcha), southwest Australia (Lake Stubbs, Lake Orr, Lake King, Lake Tay and Lake Chlorine) and Cape Verde (including artificial solar salt ponds at Santa Maria and the Pedra Lume caldera, which is filled with oceanic water). However, none of these measurements showed significantly enhanced $\mathrm{BrO}$ or iodine oxide (typically less than $2 \mathrm{ppt}$ for multi-axis (MAX) DOAS measurements). A model study by Tas et al. (2006) focusing on the Dead Sea emphasized the possibly important role of aerosols for the release of reactive bromine, while another study by Smoydzin and von Glasow (2009) suggested an additional direct bromine release from sea water. The autocatalytic reaction cycle that is associated with the rapid production of $\mathrm{BrO}$ (the so-called "bromine explosion", Platt and Lehrer, 1997) could recently be observed under laboratory conditions within a smog chamber (Buxmann et al., 2012). In this study, environmental conditions like salt composition, $\mathrm{pH}$ value, temperature and relative humidity $(\mathrm{RH})$ were varied and a $\mathrm{BrO}$ build-up above a model salt pan could be studied in detail, indicating a strong dependency on RH - possibly controlled by the thickness of resulting water microlayers on the salt crust. However, the detailed chemical mechanism still remains unclear as corresponding model calculations were not able to reproduce the findings.

\subsection{The Rann of Kutch}

The Rann of Kutch is a "seasonal salt marsh", stretching from the Indo-Pakistani border into the Kutch District of India's largest state, Gujarat. With more than $30000 \mathrm{~km}^{2}$ it is the largest salt desert in the world and additionally one of the hottest areas of India, with summer temperatures around $50^{\circ} \mathrm{C}$ and winter temperatures decreasing below $0{ }^{\circ} \mathrm{C}$ during night. The Rann (the name originates from the Hindi word for desert) can be subdivided into a large northern part ("Great Rann of Kutch") and the considerably smaller "Little Rann of Kutch" (Fig. 1), located on the southeastern border of Gujarat. During India's summer monsoon (June/JulySeptember/October), the flat desert of salty clay and mudflats (which lies, on average, $15 \mathrm{~m}$ a.s.l.) is flooded by tidal water as well as freshwater from nearby rivers and standing water from extensive rainfall (Fig. 2). Due to these rather extreme climatic conditions, the area is widely uninhabited. After the monsoon season, the accumulated shallow water layer evaporates, leaving large parts of the Rann covered by a snowwhite salt crust.

Large industrial evaporation ponds are located near the coast of the Great and Little Rann of Kutch (indicated by areas marked in red in Fig. 2a, left) and used for the production of salt and the subsequent recovery of elemental bromine from sea bittern, i.e. mother liquor left after the recovery of common sodium chloride from brine (Mehta et al., 2003). All over the Little Rann, in particular, the salt is also harvested from hand-built salt evaporation ponds that are constructed by thousands of local families year after year (Pacha, 2013), after having been destroyed by the annually recurring monsoon flood (see also Figs. S1-S3 of the Supplement).

Atmospheric measurements by ground-based instruments have not been performed in the Rann of Kutch yet, probably due to the difficult climatic conditions. Satellite observations, however, provide the unique possibility to investigate the entire area remotely over a long time period.

\section{Instruments}

\subsection{Ozone Monitoring Instrument}

The Ozone Monitoring Instrument (OMI) is part of NASA's Earth Observation System (EOS) program and is carried by the Aura satellite, launched in July 2004 into a sunsynchronous polar orbit at $705 \mathrm{~km}$ altitude (Levelt et al., 2006). Aura crosses the equator at about 13:30 LT. The three 


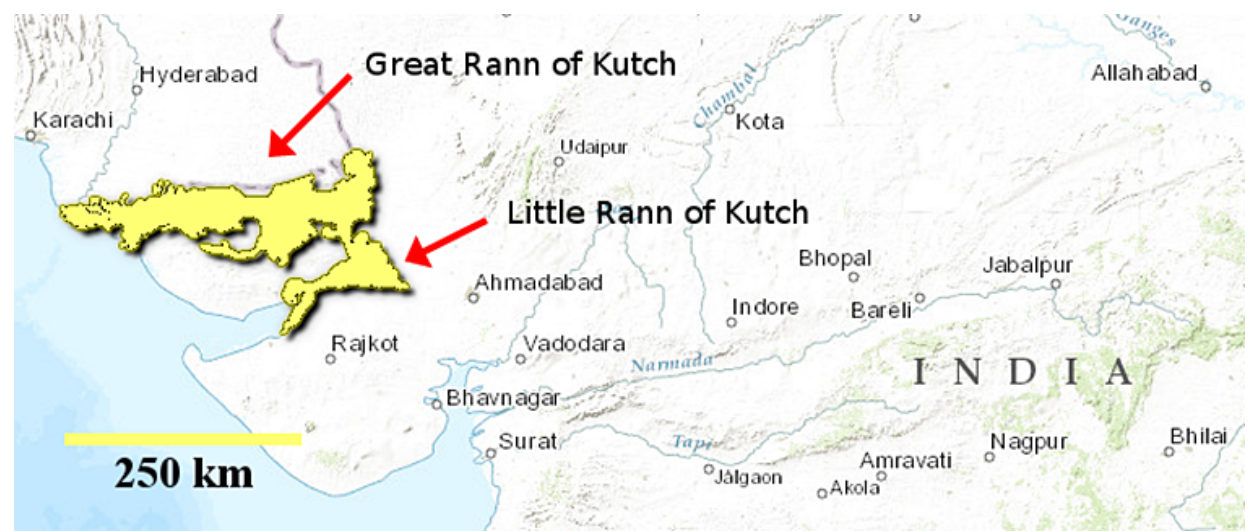

Figure 1. Location of the Great and Little Rann of Kutch. While about $10 \%$ of the Great Rann belong to Pakistan, the main part as well as the Little Rann are located in the Kutch District of Gujarat, India (adapted from Fund, W.: Rann of Kutch seasonal salt marsh, 2014. Retrieved from http://www.eoearth.org/view/article/155658, last access on 28 January 2016, CC BY-SA 2.5).

channel UV/Vis push-broom spectrometer covers a wavelength range from $270-500 \mathrm{~nm}$ at a moderate spectral resolution of $0.42-0.63 \mathrm{~nm}$. Featuring a two-dimensional charge coupled device $(\mathrm{CCD})$ detector with a near-nadir ground pixel size of $13 \times 24 \mathrm{~km}^{2}$ (up to $28 \times 150 \mathrm{~km}^{2}$ at the swath edge) and a large swath width of $2600 \mathrm{~km}$, the measurements achieved daily global coverage until the first appearance of the so-called "row anomaly" in June 2007. Today, global coverage is achieved after 2 days, as almost half of the OMI ground pixels are affected by the "row anomaly" (KNMI, 2015). So far, OMI has been successfully used to monitor enhanced $\mathrm{BrO}$ vertical column densities (VCDs) during polar spring, associated with the ODEs (e.g. Salawitch et al., 2010; Choi et al., 2012) and during volcanic eruptions (Theys et al., 2014).

\subsection{Global Ozone Monitoring Experiment-2}

The second generation of the Global Ozone Monitoring Experiment (GOME-2) is a series of three identical instruments that are part of the MetOp satellite program operated by the European Organisation for the Exploitation of Meteorological Satellites (EUMETSAT). The first GOME-2 instrument, GOME-2A, is carried by MetOp-A and was launched into a sun-synchronous polar orbit at $800 \mathrm{~km}$ altitude in October 2006 (Callies et al., 2000). The second instrument (GOME2B, carried by MetOp-B) was launched in September 2012; GOME-2C will be carried by the MetOp-C satellite to be launched in 2018. MetOp-A crosses the equator at about 09:30 LT. In this study, only GOME-2A observations are analysed.

The GOME-2A instrument is a four-channel UV/Vis grating spectrometer that observes the Earth's atmosphere in near-nadir viewing geometry. Originally, a scanning mirror provided a cross-track swath width of $1920 \mathrm{~km}$ (at observation angles up to $50^{\circ}$ off-nadir) resulting in global coverage within 1.5 days (EUMETSAT, 2005; Munro et al.,
2006). GOME-2A measures both the radiance of sunlight reflected by the Earth's atmosphere and the solar irradiance, covering the wavelength region of $240-790 \mathrm{~nm}$ at a moderate spectral resolution of $0.2-0.4 \mathrm{~nm}$. With a nadir pixel size of $40 \times 80 \mathrm{~km}^{2}$, GOME-2A observed 4 times smaller ground pixels than its predecessor GOME on ERS-2 (European Remote Sensing Satellite 2), but they were 10 times larger when compared to OMI ground pixels (see Sect. 2.1). After several test configurations in early 2013, the swath width of GOME-2A was reduced to $960 \mathrm{~km}$ (nadir pixel size of $40 \times 40 \mathrm{~km}^{2}$ ) to achieve daily global coverage via the socalled "tandem operation" mode together with GOME-2B, which covers the remaining daily gaps. Like OMI, GOME$2 \mathrm{~A}$ data have been successfully used to observe enhanced tropospheric $\mathrm{BrO}$ VCDs during polar spring (e.g. Begoin et al., 2010; Theys et al., 2011; Sihler et al., 2012) and during volcanic eruptions worldwide (Theys et al., 2009a; Hörmann et al., 2013).

\section{BrO DOAS retrieval}

The data of both satellite instruments were analysed at the Max Planck Institute for Chemistry (MPI-C) for BrO column densities by using the DOAS technique (Platt and Stutz, 2008). The GOME-2 data were evaluated using the algorithm developed by Sihler et al. (2012). The OMI BrO retrieval follows the general settings of the GOME-2 retrieval: a wavelength range from 336 to $360 \mathrm{~nm}$ was used, covering four adjacent absorption bands. In addition to the $\mathrm{BrO}$ cross section from Wilmouth et al. (1999), ozone cross sections at 223 and $243 \mathrm{~K}$ (Gür et al., 2005), $\mathrm{O}_{4}$ (Greenblatt et al., 1997), $\mathrm{NO}_{2}$ (Vandaele et al., 2002), OClO (Bogumil et al., 2003) and $\mathrm{SO}_{2}$ (Bogumil et al., 2003) were used. Furthermore, two Ring spectra (one calculated for a sun reference spectrum, the other one using the former scaled by $\lambda^{4}$ ), an inverse ref- 

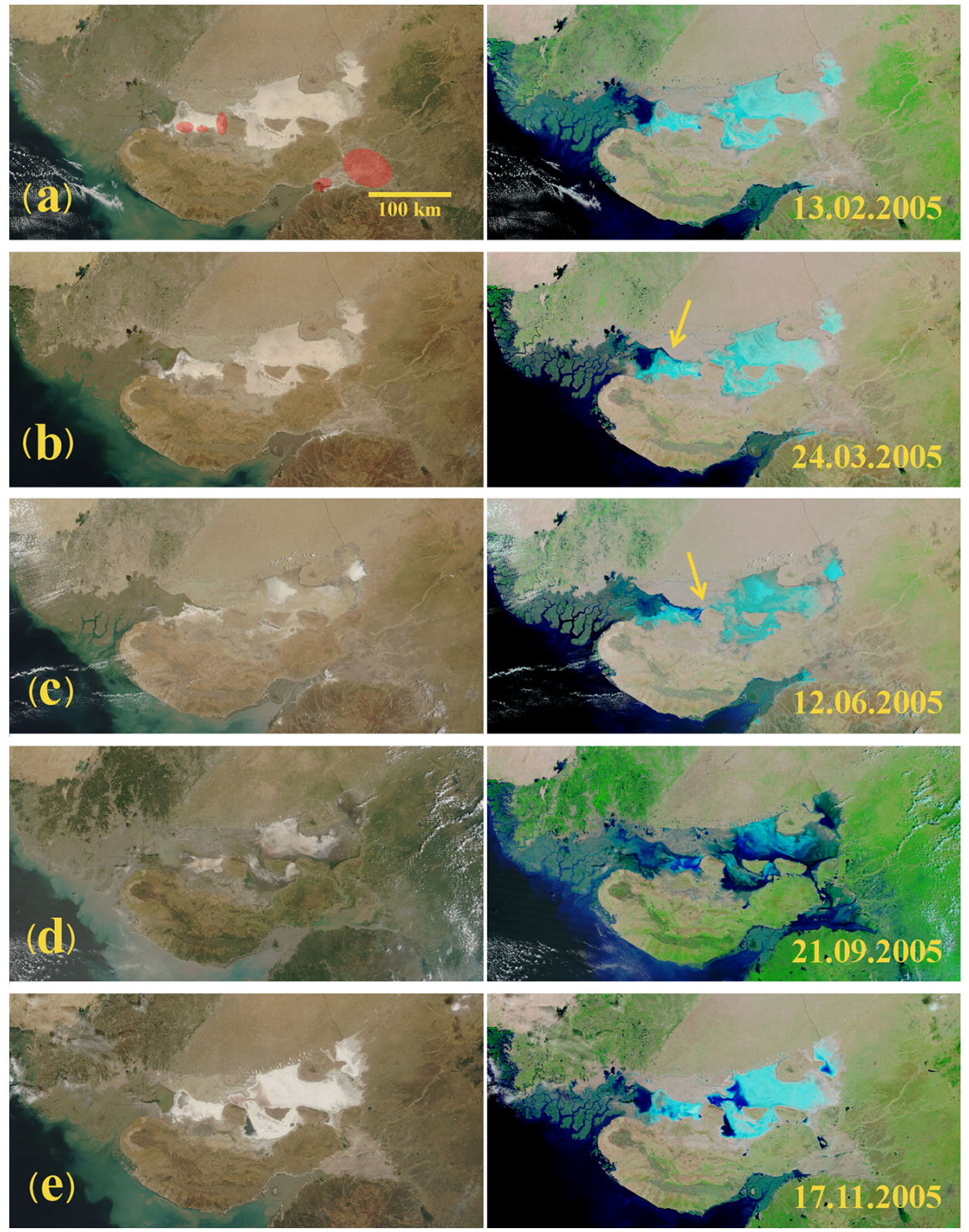

Figure 2. MODIS True Color (TC, left) and Band 7-2-1 images (right) over the Rann of Kutch for selected days in (a) February, (b) March, (c) June, (d) September and (e) November 2005 (13.2., 24.3. 12.6., 21.9. and 17.11.), illustrating the flood during the monsoon. Water can be identified from the 7-2-1 images as dark blue/black, while clouds and bright surfaces appear light blue. The Rann appears as a bright surface earlier in the year, before it darkens due to inflowing water (indicated by yellow arrows in (b) and (c), right column; compare with the mean reflectivity shown in Fig. 4). During monsoon time, the entire Rann is often completely flooded and large areas are dominated by mud (TC image in September). Locations of industrial evaporation ponds are indicated by areas marked in red in (a).

erence spectrum and a fifth-order polynomial were included in the $\mathrm{BrO}$ retrieval.

OMI data affected by the row anomaly (first appearing after 25 June 2007) were excluded from the retrieval (KNMI, 2015). Due to differences in the measurement sensitivity of single $\mathrm{CCD}$ detector pixels, $\mathrm{OMI} \mathrm{BrO}$ column density maps suffer from cross-track striping, which is especially apparent for weak absorbers like BrO. To overcome the striping effect, mean geometrical $\mathrm{BrO} \mathrm{VCDs}$ (appropriate for a stratospheric absorber) calculated for each pixel row individually over a remote area over the Pacific $\left( \pm 20^{\circ} \mathrm{N}, 105-175^{\circ} \mathrm{W}\right)$ were subtracted from all daily measurements. Since the contribution of stratospheric $\mathrm{BrO}$ to the total column is hereby removed as well, the median $\mathrm{BrO}$ column across the track was re-added. Please note that the BrO VCDs finally used in this study are 
corrected for the stratospheric contribution to the total column by a specifically local separation (see Sect. 3.2).

The measured spectra are additionally affected by permanent and transient hot pixels, leading to increased noise at certain wavelengths for individual CCD detector rows. Such erroneous measurements can be easily identified by abnormally large fitting residuals at affected wavelength positions and again lead to strongly elevated BrO VCD stripes. Following the suggestions by Chance (2007), intensities measured at pixels showing very strong residual discrepancies $(>4 \sigma)$ from an initial fit were excluded for a final second fit. The vast majority of former suspiciously anomalous $\mathrm{BrO}$ slant column densities (SCDs) showed realistic columns similar to nearby measurements after the correction.

\subsection{Clouds}

The observation of tropospheric trace gases is significantly affected by radiative transfer due to cloud coverage in several ways. If the trace gas is located above a thick cloud layer, satellite measurements might show an increased sensitivity. On the other hand, clouds may completely shield trace gases close to the surface. To minimize the influence of clouds, only OMI measurements with an effective cloud fraction of less than $30 \%$ were considered. For this purpose two operational Level 2 OMI cloud products are provided by NASA:

1. OMCLDO2, for cloud detection using the $\mathrm{O}_{2}-\mathrm{O}_{2}$ absorption near $477 \mathrm{~nm}$ (e.g. Acarreta and de Haan, 2002; Vasilkov et al., 2008)

2. OMCLDRR, using information from the so-called filling-in of solar Fraunhofer lines caused by rotational Raman (RR) scattering in the atmosphere (Ring effect) within the 346-354 nm spectral range (e.g. Joiner et al., 2002; Stammes et al., 2008).

Although the OMCLDO2 algorithm is most commonly used, it turned out that the algorithm almost always misclassifies the bright surface of the salt marsh as cloud and is thereby unsuitable for the $\mathrm{BrO}$ analysis presented here. In contrast, the OMCLDRR algorithm seems to better distinguish between the bright surface and clouds, probably because of an increased contrast in the UV in comparison to the visible wavelength range that is used in the OMCLDO2 algorithm. It should, however, be noted that a reanalysis of the data applying a lower cloud filter threshold of only $20 \%$ showed that the OMCLDRR algorithm sometimes misinterprets the bright surface of the salt marsh as clouds as well. This is in particular the case during the first 34 months after the Rann is flooded (October/NovemberDecember/January). As the remaining water evaporates, a very clean and bright surface remains as indicated by increased reflectivity; this effect can be seen in MODIS True Color images as in Fig. 2. In order to provide statistically relevant monthly averaged $\mathrm{BrO}$ VCDs, only grid pixels that were covered at least 10 times by the daily measurements were finally taken into account. It can, however, not be completely ruled out that some of the actual cloud-free measurements are sorted out using the cloud filter.

For GOME-2, the only available cloud detection algorithms are the operational FRESCO (Koelemeijer and Stammes, 2001; Koelemeijer et al., 2002) and ROCINN (Loyola R., 2004; Rozanov et al., 2006) products, which both use wide parts of the oxygen A-band spectrum to determine the effective cloud fraction. Similar to the OMI OMCLDO2 algorithm, both FRESCO and ROCINN fail to distinguish between the bright surface of the salt marsh and clouds. Therefore only a qualitative comparison of the unfiltered cloudy data will be presented in Sect. 4.5.

\subsection{Local stratospheric background correction}

Because all satellite measurements include the total atmospheric BrO column, the data have to be corrected for the stratospheric fraction to retrieve the tropospheric BrO column over the salt marsh area. The stratospheric BrO distribution varies little with latitude and even less with longitude (Theys et al., 2009b) and on much larger spatial scales than the variations of the $\mathrm{BrO}$ enhancement observed over the Rann of Kutch. Therefore, BrO VCDs determined assuming a geometrical air mass factor were corrected by subtracting the results of a two-dimensional spatial polynomial fit of third degree $n$ applied to the daily measurements as described in Hörmann et al. (2013):

$V_{\text {trop }, i}^{*} \approx V_{\text {tot }, i}^{*}-\sum_{m, n=0}^{3} V_{\text {strat }, i}^{*} \times x_{i}^{m} \times y_{i}^{n}$,

where $V_{\text {strat }, i}^{*}$ is the fitted stratospheric BrO VCD at the centre coordinates $x$ and $y\left({ }^{\circ}\right)$ of satellite pixel $i$ within a large area around the Rann of Kutch $\left(18-30^{\circ} \mathrm{N}, 62-78^{\circ} \mathrm{E}\right)$. To minimize the influence of possibly enhanced BrO VCDs over the salt marsh, the actual Rann area $\left(22.5-25.5^{\circ} \mathrm{N}, 67.5-\right.$ $72.5^{\circ} \mathrm{W}$ ) was excluded from the polynomial fit of the stratospheric correction approach. A qualitative comparison of our stratospheric $\mathrm{BrO}$ estimation with the more sophisticated approach presented by Theys et al. (2009b) shows similar results and typical $V_{\text {strat }}$ of about $2.5 \times 10^{13} \mathrm{molec}^{-2}$. The resulting corrected geometrical $\mathrm{BrO} \operatorname{VCDs}\left(V_{\text {trop }}^{*}\right)$ were reconverted into "tropospheric" SCDs $\left(S_{\text {trop }}^{*}\right)$ by multiplication with the geometrical AMF.

\subsection{Radiative transfer}

As the radiative transfer for a tropospheric absorber is not adequately represented by the geometrical approximation, the "tropospheric" $S_{\text {trop }}^{*}$ were multiplied with box air mass factors (box-AMF) calculated by the Monte Carlo radiative transfer model (RTM) McArtim (Deutschmann et al., 2011) to retrieve final BrO VCDs. The simulations were conducted near the strongest $\mathrm{BrO}$ absorption band $(338.5 \mathrm{~nm})$ assuming 
cloud-free conditions. Two main model runs were performed for different homogeneous BrO layer profiles $(0-400 \mathrm{~m}, 0$ $1 \mathrm{~km}$ and $0-2 \mathrm{~km})$ :

1. no additional aerosols (varying surface albedo of 0.10 , 0.15 and 0.20 )

2. additional homogeneous aerosol layer at $0-1 \mathrm{~km}$ (single-scattering albedo (SSA): 0.9; asymmetry parameter (AP): 0.72; and varying aerosol optical depth (AOD) of $0.4,0.7$ and 1 ).

As baseline properties, a surface albedo of 0.15 (based on typical OMI reflectivity values at $331 \mathrm{~nm}$; available via the NASA OMSO2 Level $2 \mathrm{OMI} \mathrm{SO}_{2}$ product and briefly described in Carn et al., 2013), a homogeneous BrO layer at $0-1 \mathrm{~km}$ and an AOD of 0.7 were chosen. All baseline aerosol property assumptions (AOD, SSA and AP) were based on monthly mean OMI observations at $342.5 \mathrm{~nm}$ (via the NASA OMAEROG Level 2 aerosol product, described in Torres et al., 2007). As the OMAEROG product often shows unrealistically high parameter values exclusively over the Rann area (e.g. monthly mean AODs of more than 4), the product seems to have some problems with the exceptionally bright surface of the salty desert. Additionally, the associated parameters seem to be affected by increased cloud coverage during the monsoon season.

In order to estimate the actual aerosol parameters despite these problems, mean values for AOD, SSA and AP close to (but outside of) the Rann area were chosen. An estimate of the uncertainties caused by the a priori assumptions will be given in Sect. 4.2.

\section{Results}

The individual daily measurements of each month from October 2004 to December 2014 were gridded on a regular lat-long grid with a spatial resolution of $0.1^{\circ}$, from which monthly mean BrO VCD maps were calculated. Figure 3 shows the monthly mean BrO VCDs (10-year averages for 2004-2014) for baseline radiative transfer (RT) settings (see Sect. 3.3). It is clearly visible from the maps that the BrO VCDs slowly rise during the first months of each year and reach a maximum during April/May $\left(\approx 6 \times 10^{13} \mathrm{molec} \mathrm{cm}^{-2}\right)$. In the second half of the year, the values are much lower. During the monsoon (JuneSeptember), the enhancement almost completely disappears. The low values during the monsoon are, however, at least partly caused by the shielding effect of remaining cloud cover over the observed area (as additionally indicated by enhanced background noise in the southeastern part of the region shown due to the reduced statistics). After the monsoon (October-December) the BrO VCDs remain at a low level, reaching magnitudes similar to those found at the beginning of the year. Although the individual years 20042014 partly show a less prominent seasonal variation of the absolute $\mathrm{BrO}$ VCDs over the salt marsh, the temporal evolution is similar for all analysed years (see Supplement for all time series). The annual mean $\mathrm{BrO} \mathrm{VCD}$ maxima were mostly found during April (2006-2009, 2011-2014) and twice in May $(2005,2010)$, with a 10 -year maximum of about $1.4 \times 10^{14} \mathrm{molec} \mathrm{cm}^{-2}$ in April 2009 .

Regarding the Great Rann of Kutch, a closer look at the annual pattern indicates that the BrO VCDs typically first rise in the western part during March, before clearly enhanced VCDs can be seen over the whole area in April and mostly over the middle/eastern part during May (Fig. 3, MarchMay). It remains unclear if this behaviour originates in the different ambient conditions in different areas and months or if it is caused by transport due to a steady westerly wind (see Sect. 4.4 and Fig. 7). A significant contribution of halogen emissions from the large artificial evaporation ponds that are used for salt/bromine mining is unlikely, as no trend can be seen from the measurements although the industrial facilities were massively expanded after 2009 (see Supplement for MODIS observations of these industrial complexes).

The maximum BrO VCDs over the Little Rann of Kutch are generally lower compared to the Great Rann, with a maximum of $6.1 \times 10^{13} \mathrm{molec} \mathrm{cm}^{-2}$ in May 2010. Like for the Great Rann, the annual maximum BrO VCDs typically appear during April-May but remain at a very low level close to the detection limit for all other months (Fig. 3). Even during April and May, the maximum BrO VCDs over the Little Rann are about a factor of 3 lower than over the Great Rann.

\subsection{Variation of surface reflectivity and sensitivity}

The strongly enhanced albedo of the salty crust is expected to have a significant effect on the sensitivity for near-surface $\mathrm{BrO}$. This may lead to apparently enhanced BrO VCDs over the Rann when compared to nearby areas featuring a lower albedo due to a potentially enhanced tropospheric BrO background and the underestimation of the corresponding AMF. To investigate the possible influence of the bright surface on the spatial pattern of BrO VCDs, the reflectivity at $331 \mathrm{~nm}$ as seen by OMI (see Sect. 3.3) was used to calculate monthly averaged maps for the same data that were used for the $\mathrm{BrO}$ VCD maps (i.e. using a cloud filter $\mathrm{CF}<30 \%$ ). Figure 4 shows the resulting mean reflectivity at $331 \mathrm{~nm}$ for 10-year averaged months during 2004-2014. At first glance, especially the northern Great Rann of Kutch can be clearly identified for all months outside the monsoon season by the strongly increased reflectivity. During the monsoon (JuneSeptember) the shape of the salt marsh vanishes as the area is flooded and more and more (bright) clouds shield the Rann (despite the applied cloud selection criteria). The extensive cloud coverage generally leads to a widely enhanced mean reflectivity over the whole investigated area, especially the Indian mainland. After the monsoon, the mean reflectivity is typically even higher (20-23\%) than during the first months of the year (15-20\%), probably because the evaporating wa- 


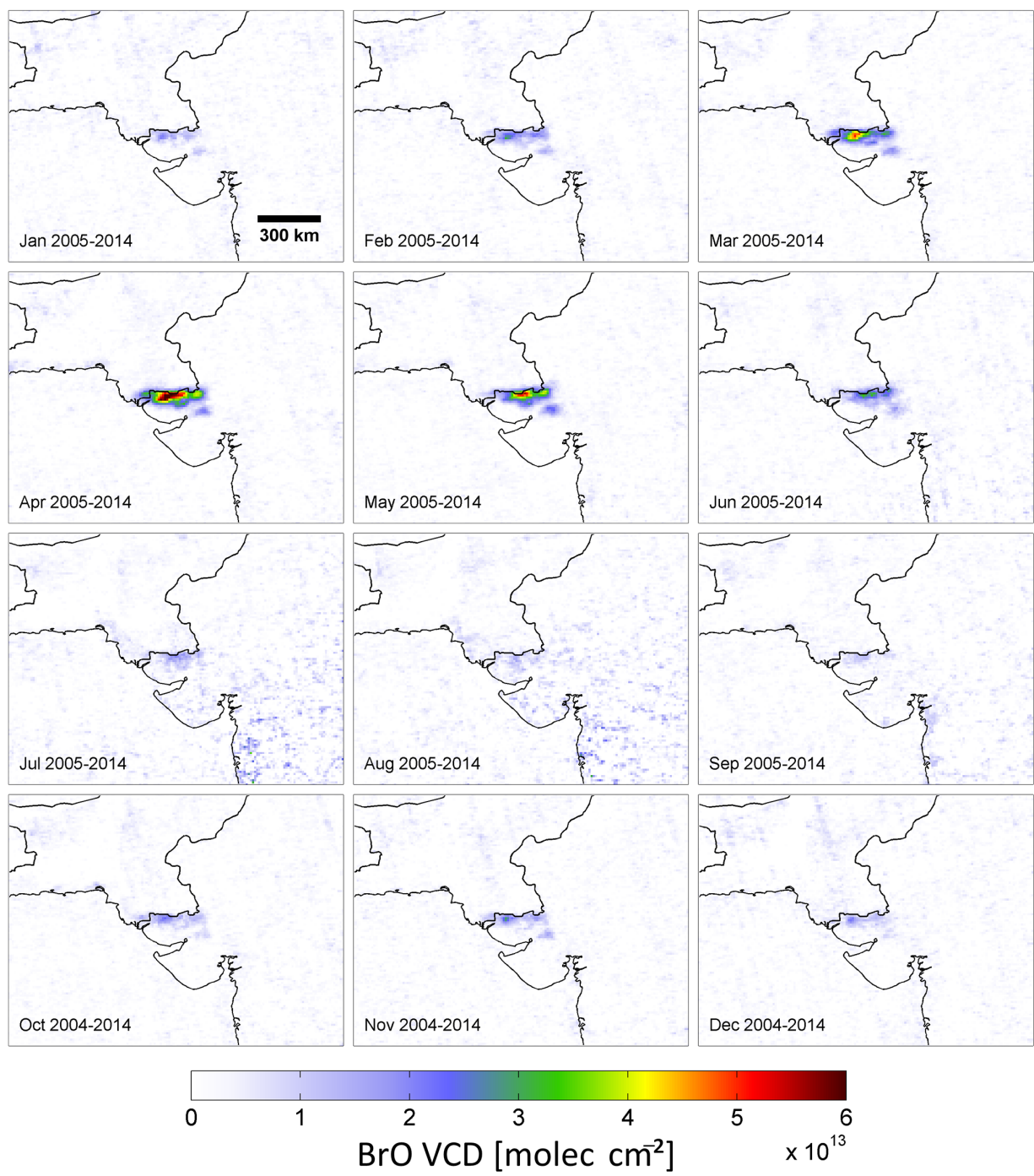

Figure 3. Seasonal variation of monthly mean BrO VCDs with $\mathrm{CF}<30 \%$ over the Rann of Kutch as seen by OMI during $2004-2014$. While maximum VCDs are clearly detected in April and May for the Great and Little Rann, only small enhancements can be seen during wintertime. Results during the monsoon season (July-September) include less measurements due to increased cloud frequency leading to a higher noise level, especially in the southeastern part of the region shown. Please note that OMI data are only available from October 2004 onwards, i.e. no data for January-September 2004 are included.

ter leaves a clean, bright and salty crust. This effect can also be recognized in the corresponding MODIS True Color images (compare Fig. 2). A comparison of Figs. 3 and 4 leads to the interesting finding that the reflectivity is smallest during months that typically show the highest BrO VCDs (April and May). The minimum reflectivity over the Great Rann appears for May 2005-2014 (as well as for most individual years; see Supplement for all time series). Maximum BrO VCDs are found in April 2005-2014. Almost no BrO VCD enhancement can be observed after the monsoon months, whereas the reflectivity is highest. Generally, there is no strong spatial correlation of the BrO VCDs to the mean reflectivity patterns. While there is only little variation in the regional reflectivity within the Rann area over different months, the spatial distribution of $\mathrm{BrO}$ VCDs changes and even seems to progress into the eastern part of the Great Rann from March to May.

In contrast to the Great Rann, the Little Rann cannot be clearly identified from averaged reflectivity maps as corresponding values stay close to surrounding areas $(\approx 7-10 \%)$, with the lowest values occurring during May 2005-2014, when enhanced $\mathrm{BrO}$ VCDs clearly show up.

\subsection{Estimation of total BrO mass and mixing ratio}

To estimate the total amount of $\mathrm{BrO}$ for each month, the $\mathrm{BrO}$ VCDs within the Rann area $\left(22.5-25.5^{\circ} \mathrm{N}, 67.5-72.5^{\circ} \mathrm{E}\right)$ were summed up and converted into total masses $\left(M_{\mathrm{BrO}}=\right.$ 

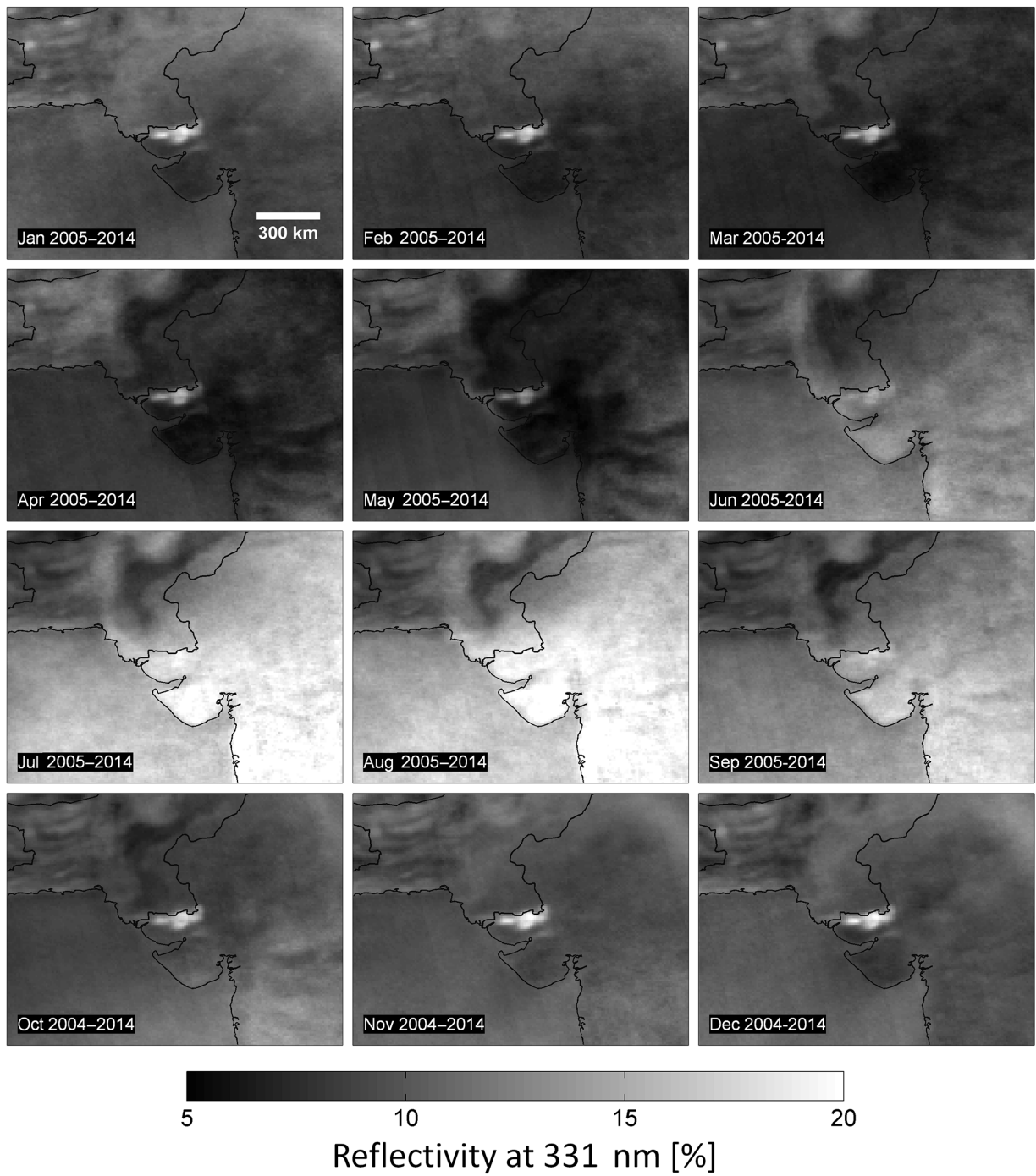

Figure 4. Seasonal variation of the monthly mean reflectivity at $331 \mathrm{~nm}$ over the Rann of Kutch as seen by OMI during $2004-2014$ (same data selection as in Fig. 3, i.e. for $\mathrm{CF}<0.3$ ). Only the Great Rann of Kutch can be clearly identified due to its bright surface compared to the surrounding areas. During the monsoon (July-September), wide areas are still affected by clouds as indicated by the increased background, including the Rann area. It is important to note that enhanced BrO VCDs in Fig. 3 appear only in certain parts of the salt marsh (area of enhanced reflectivity) and especially for rather low reflectivity in April and May.

$95.903 \mathrm{~g} \mathrm{~mol}^{-1}$ ) by assuming the aforementioned baseline properties (i.e. a BrO layer thickness of $1 \mathrm{~km}$; see Sect. 3.3). Figure 5 shows the resulting $\mathrm{BrO}$ mass over the Rann in the time period between October 2004 and December 2014 (blue areas) next to the $\mathrm{BrO}$ mass determined from a neighbouring reference area of the same size to the west of the Rann region (red line). For the sake of clarity, all measurements that fall within the monsoon season (June-September) are indicated in green. Corresponding reflectivity values are shown by the blue dotted line.

The largest $\mathrm{BrO}$ amount can be regularly observed in April and May, ranging from $2100 \mathrm{t}$ in May 2007 up to $4700 \mathrm{t}$ in May 2010. Taking into account all OMI measurements, the mean $\mathrm{BrO}$ mass during spring (March-May) is calculated to be $(2700 \pm 917) t$, where the uncertainty represents the corresponding standard deviation $\sigma$. In contrast, the mean mass over the reference area was found to be about a factor of 13 lower $(212 \pm 105) t$. The deviation from zero can probably be attributed to the imperfect polynomial correction for the stratospheric $\mathrm{BrO}$ background. During the monsoon season (June-September) the $\mathrm{BrO}$ mass declines over the Rann and remains at a comparatively low level of $(1066 \pm 753) t$, often followed by a local maximum directly after the monsoon (October) before another minor drop leads to an annual minimum around December. While the mean $\mathrm{BrO}$ masses over the Rann during the monsoon are still about 3 times 


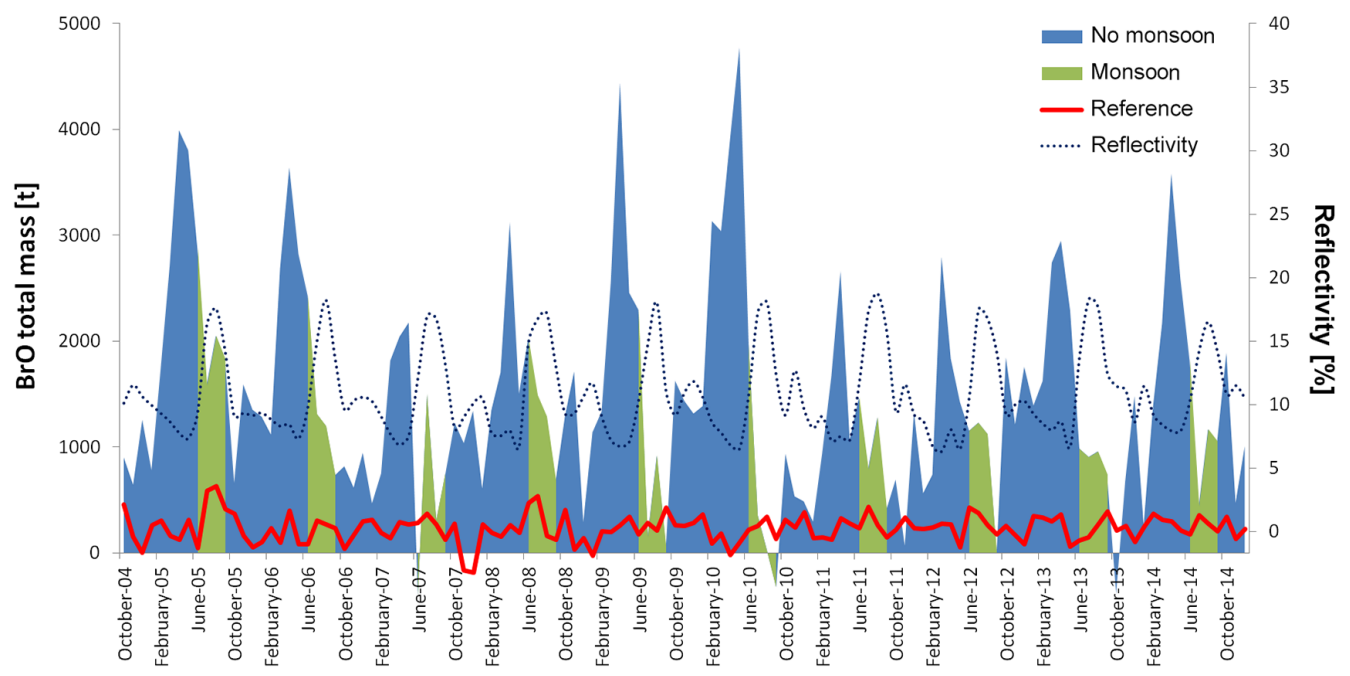

Figure 5. Total BrO mass over the Rann of Kutch area calculated from monthly averaged BrO VCD OMI data for the baseline scenario (i.e. a homogeneous layer reaching from the surface up to $1 \mathrm{~km}$ ) from October 2004 until December 2014. During monsoon months (green) the reflectivity (blue dotted line) shows maximum values due to cloud coverage, while the BrO mass is lowered (partly due to cloud shielding). Maximum $\mathrm{BrO}$ masses are typically accompanied by a rather low reflectivity. For comparison, BrO masses obtained over a corresponding reference area of the same size directly west of the considered region are indicated by the red line.

larger than over the corresponding reference area for most years $(279 \pm 138 \mathrm{t})$, they are associated with a high uncertainty due to the influence of cloud coverage and associated small number of measurements. In this context it should be mentioned that the reference area is generally less affected by (convective/orographic) clouds as large parts are located over the Arabian Sea. During wintertime (NovemberFebruary), the mean $\mathrm{BrO}$ masses remain at the same low level $(1067 \pm 560 t)$ for the area over the Rann, $(187 \pm 131 \mathrm{t}$ over the reference area); however, the uncertainties are now much smaller as the Rann region is only sporadically affected by clouds.

Assuming a standard atmosphere and the baseline properties for the BrO layer $(0-1 \mathrm{~km})$, mixing ratios of $20-66 \mathrm{ppt}$ maximum can be roughly estimated from the maximum $\mathrm{BrO}$ VCDs during March-May 2005-2014 (mean mixing ratio: $35 \pm 10 \mathrm{ppt}$ ). In reality, however, the mixing ratios remain highly uncertain as the true atmospheric properties (in particular the $\mathrm{BrO}$ vertical profile and the aerosol amount) are unknown. To point out the strong influence of all presumed parameters on the mixing ratio estimation (i.e. the AMF calculation and the assumption of the $\mathrm{BrO}$ layer height), Table 1 shows the results for a variation of all key parameters in comparison to the baseline scenario. While varying aerosol parameters or even the general presence of aerosols (i.e. $\mathrm{AOD}=0)$ only leads to small changes $(-8$ to $6 \%)$ in the estimated $\mathrm{BrO}$ mixing ratio, a variation of the surface albedo $(-14$ to $20 \%)$ and especially the BrO layer thickness ( -23 to $34 \%$ ) has a rather strong effect on the corresponding mixing ratios. Overall, the final uncertainties can be estimated to be about -33 to $73 \%$.

\subsection{Correlation with meteorological parameters}

The influence of meteorological parameters on the "bromine explosion" reaction cycle is still largely unclear and remains a subject of intensive discussion within the scientific community. Whereas, for example, the role of blowing snow in the activation of bromine over first-year Antarctic sea ice has recently been analysed in situ (Lieb-Lappen and Obbard, 2015), the influence of environmental conditions like temperature, relative humidity or $\mathrm{pH}$ value at salt lakes was almost exclusively investigated by using an artificial salt pan within a smog chamber (Buxmann et al., 2012). It was found that the corresponding $\mathrm{BrO}$ mixing ratios were almost 1 order of magnitude higher at a relative humidity of $60 \%$ when compared to experiments at 37 or $2 \%$. This is probably caused by quasi-liquid water layers on the salty crust that seem to support the activation of reactive bromine.

To investigate possible dependencies of the observed total BrO mass over the Rann of Kutch on humidity and other parameters, data from the European Centre for MediumRange Weather Forecasts (ECMWF) for the whole investigated time period and within a $1^{\circ} \times 1^{\circ}$ area located over the central part of the Great Rann $\left(23.5-24.5^{\circ} \mathrm{N}, 69-70^{\circ} \mathrm{E}\right)$ were used to calculate monthly averaged values for different meteorological parameters around the time of the OMI overpass (09:00 UTC). Figure 6 shows the annual variation of the $\mathrm{BrO}$ mass together with total precipitation $(P)$, cloud coverage $(\mathrm{CC})$, relative humidity $(\mathrm{RH})$, temperature $(T)$, boundary layer height $(\mathrm{BLH})$ and $\mathrm{UV}$ radiation at the surface $\left(\mathrm{UV}_{\mathrm{rad}}\right)$. At first glance, the parameters can be divided into two groups by their seasonal behaviour (indicated by different colours 
Table 1. Uncertainty of $\mathrm{BrO}$ mixing ratio estimation based on the variation of assumed properties (BrO profile, surface albedo, aerosol optical density) for the AMF calculation.

\begin{tabular}{lrrrr}
\hline A priori & Baseline & Alternatives & Mixing ratio [ppt] & $\Delta \mathrm{BrO}[\%]$ \\
\hline \multirow{2}{*}{ Layer profile } & $0-1 \mathrm{~km}$ & $\begin{array}{r}0-400 \mathrm{~m} \\
0-2 \mathrm{~km}\end{array}$ & $\begin{array}{r}(47 \pm 13) \mathrm{ppt} \\
(27 \pm 8) \mathrm{ppt}\end{array}$ & $+34 \%$ \\
& & $0 *$ & $(32 \pm 9) \mathrm{ppt}$ & $-8 \%$ \\
\hline \multirow{2}{*}{ AOD } & 0.7 & 0.4 & $(34 \pm 10) \mathrm{ppt}$ & $-3 \%$ \\
& & 1.0 & $(37 \pm 11) \mathrm{ppt}$ & $+6 \%$ \\
\hline \multirow{2}{*}{ Surface albedo } & 0.15 & 0.1 & $(42 \pm 12) \mathrm{ppt}$ & $+20 \%$ \\
& & 0.2 & $(30 \pm 9) \mathrm{ppt}$ & $-14 \%$ \\
\hline
\end{tabular}

$* \mathrm{AOD}=0$ corresponds to a non-aerosol scenario.

for left and right column in Fig. 6a-f). While $P, \mathrm{CC}$ and $\mathrm{RH}$ are closely related to the Indian monsoon, $T$, BLH and $\mathrm{UV}_{\text {rad }}$ are closely related to each other via their dependence on solar irradiation. The latter three parameters correlate very well with the total $\mathrm{BrO}$ mass during the first half-year, before a second maximum appears after the end of the monsoon. Focusing on the first half-year (i.e. the gradual increase in observed BrO VCDs starting in January until the beginning of the monsoon season in June), a linear fit applied to the $\mathrm{BrO}$ mass leads to high correlation coefficients for $T$ $\left(r^{2}=0.87\right)$, BLH $\left(r^{2}=0.93\right)$ and $\mathrm{UV}_{\text {rad }}\left(r^{2}=0.85\right)$. In contrast, the other parameters show no correlation to the $\mathrm{BrO}$ mass as indicated by $r^{2}$ values of $0.03(P), 0.05(C C)$ and $0.03(\mathrm{RH})$.

To further investigate whether a combination of these quantities can be used to model the annual $\mathrm{BrO}$ variation over the salt marsh, a systematic multilinear regression analysis was conducted. Starting from a single parameter up to a combination of all six ( $P, \mathrm{CC}, \mathrm{RH}, T, \mathrm{BLH}$ and $\left.\mathrm{UV}_{\mathrm{rad}}\right)$, a simple linear function was determined to describe the observed $\mathrm{BrO}$ cycle. The resulting $r^{2}$ value for each linear fit of the total $\mathrm{BrO}$ mass and individual multivariable function was finally used to indicate the goodness of fit. Figure $6 \mathrm{~g}$ depicts the model results for all functions featuring the highest $r^{2}$ value for a given number of parameters. Table 2 additionally lists the corresponding fit results and $r^{2}$ values. For a single variable, a linear function (LF) depending on the incident $\mathrm{UV}$ radiation already describes the annual $\mathrm{BrO}$ variations fairly well $\left(r^{2}=0.70\right.$, purple dashed line in Fig. $6 \mathrm{~g}$ ). As the UV radiation remains a permanent component of all resulting functions independent of the total number of fitted variables, the photochemical aspect of the bromine explosion is emphasized. Surface temperature appears to have a nearly negligible influence and is only included for the fit function featuring all six parameters $\left(r^{2}=0.97, \mathrm{LF} 6\right.$, red dashed line in Fig. 6g), showing almost identical results when compared to LF5 (including all parameters but temperature). Especially precipitation and relative humidity are clearly needed to fit the low level $\mathrm{BrO}$ variations during the monsoon and winter- time as can be seen by LF2/3 (light blue and orange dashed line in Fig. $6 \mathrm{~g}, r^{2}=0.83 / 0.91$ ). Taking into account four parameters $\left(\mathrm{UV}_{\text {rad }}, \mathrm{CC}, \mathrm{RH}\right.$ and $\left.\mathrm{BLH}\right)$ already leads to a linear function (LF4, black dashed line in Fig. 6g) that is well capable of describing all main features of the mean annual $\mathrm{BrO}$ observations $\left(r^{2}=0.95\right)$. Interestingly (but self-evidently), the features that were contributed by accounting for the precipitation appear to be widely included in the CC parameter for LF4, as both parameters are closely related to each other (the second-highest $r^{2}$ value for LF3, 0.86, was achieved by using CC instead of $P$ ).

The seasonal cycle of BrO formation over the Rann of Kutch can be described reasonably well as a linear function of meteorological parameters for the 10 years of averaged data on a monthly basis. It should, however, be noted that this simple approach fails to adequately reproduce the seasonal cycle when monthly averages from individual years are considered. In particular, the less pronounced $\mathrm{BrO}$ maxima in 2007, 2008, 2011 and 2012 are clearly underestimated and the highly variable winter months are also not very well captured by the linear functions. It has to be kept in mind that a linear model assumption of independent variables constitutes a rather simplistic approach to describe the satellite observations and can therefore only be used to get a rough idea about the general circumstances that are needed for the extensive formation of $\mathrm{BrO}$ over the salt marsh.

\subsection{Seasonal wind pattern}

Other possible parameters that might (at least indirectly) influence the bromine explosion mechanism and the observed $\mathrm{BrO}$ spatial pattern are wind speed and main direction. Figures 7 and 8 (upper panels) show the 10-year averaged monthly BrO VCDs over the Rann of Kutch along with the corresponding mean wind pattern that were calculated using daily ECMWF data (09:00 UTC). The lower panels in Figs. 7 and 8 additionally illustrate the wind speed and the frequency of different wind directions. Starting with slow northeastern winds in January $\left(\approx 2 \mathrm{~m} \mathrm{~s}^{-1}\right)$, the wind blows in easterly direction during months exhibiting strongly enhanced 

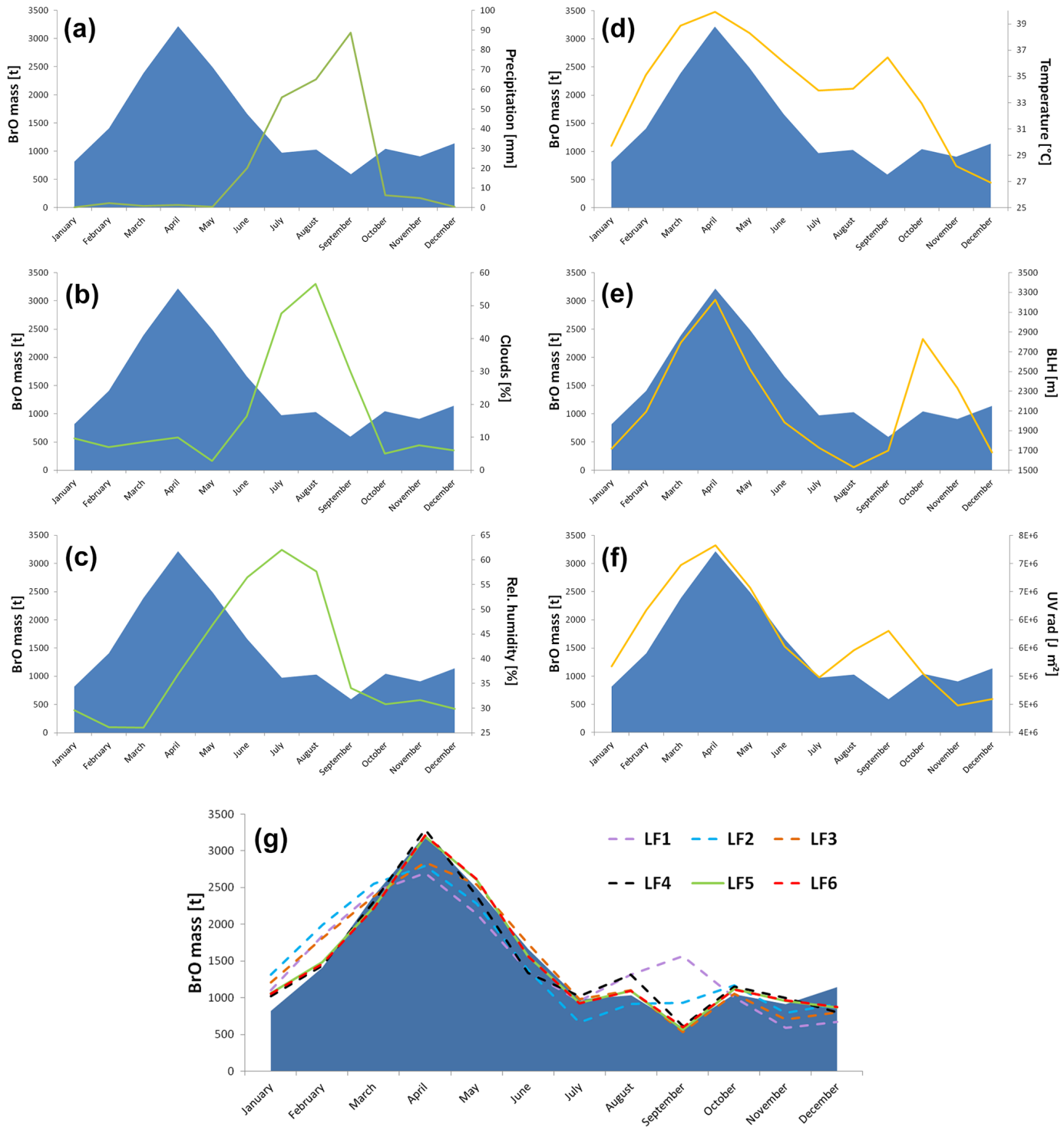

Figure 6. Monthly averaged variation of ECMWF meteorological parameters (thin lines) in comparison to the total BrO mass (blue area) over the Rann of Kutch during 2004-2014. The parameters can be divided into two groups by their seasonal behaviour (precipitation, cloud coverage and relative humidity are shown within the left column in green, a-c; surface temperature, boundary layer height and UV radiation within the right column in orange, $\mathbf{d}-\mathbf{f}$ ). The latter parameters correlate very well with the BrO mass during the first half-year, before a second maximum appears after the end of the monsoon. The results of a multilinear regression analysis suggest that a simple linear model (linear functions LF1-LF6, g) can be used to adequately describe the annual variations (see text and Table 2 for further details).

BrO VCDs (March-May). Towards the monsoon season, the winds get significantly stronger (up to $4 \mathrm{~m} \mathrm{~s}^{-1}$ in May) and reach their maximum strength in July with more than $7 \mathrm{~m} \mathrm{~s}^{-1}$ during $90 \%$ of all days, consistently coming from WSW. During these months, the strong wind speed supports the flooding of the Rann area by tidal water from the Arabian Sea. After the monsoon, the wind speed drops rapidly (1$2 \mathrm{~m} \mathrm{~s}^{-1}$ ) and the wind turns to the east again. The following winter time is dominated by calm winds from the northeast.

It is interesting to note that the distinct seasonal wind patterns over the Rann of Kutch can be linked to different phases of the observed $\mathrm{BrO}$ occurrence. Apart from the close to zero $\mathrm{BrO}$ VCDs during the monsoon months that are dominated by strong winds from the southwest, the maximum BrO VCDs in March-May are accompanied by slow westerly winds, while the low $\mathrm{BrO}$ VCDs during wintertime are influenced by slow winds from the northeast. As mentioned above, the low BrO VCDs during the monsoon are at least partly caused by cloud shielding. Outside the monsoon season, the different wind patterns lead to differences in the effective time that an air mass stays in close contact with the salty crust of the Rann. Because the Great Rann of Kutch ex- 
Table 2. Best fits from the multilinear regression analysis in order to model the seasonal BrO mass variation over the Rann of Kutch in dependency of UV surface radiation (UV), precipitation $(P)$, cloud coverage $(\mathrm{CC})$, relative humidity $(\mathrm{RH})$, boundary layer height $(\mathrm{BLH})$ and surface temperature $(T)$.

\begin{tabular}{llr}
\hline No. & Linear function & $r^{2}$ \\
\hline 1 & $m_{\mathrm{BrO}}=a_{1} \cdot \mathrm{UV}$ & 0.71 \\
\hline 2 & $m_{\mathrm{BrO}}=a_{1} \cdot \mathrm{UV}+a_{2} \cdot P$ & 0.83 \\
\hline 3 & $m_{\mathrm{BrO}}=a_{1} \cdot \mathrm{UV}+a_{2} \cdot P+a_{4} \cdot \mathrm{RH}$ & 0.91 \\
\hline 4 & $m_{\mathrm{BrO}}=a_{1} \cdot \mathrm{UV}+a_{3} \cdot \mathrm{CC}+a_{4} \cdot \mathrm{RH}+a_{5} \cdot \mathrm{BLH}$ & 0.95 \\
\hline 5 & $m_{\mathrm{BrO}}=a_{1} \cdot \mathrm{UV}+a_{2} \cdot P+a_{3} \cdot \mathrm{CC}+a_{4} \cdot \mathrm{RH}+a_{5} \cdot \mathrm{BLH}$ & 0.97 \\
\hline 6 & $m_{\mathrm{BrO}}=a_{1} \cdot \mathrm{UV}+a_{2} \cdot P+a_{3} \cdot \mathrm{CC}+a_{4} \cdot \mathrm{RH}+a_{5} \cdot \mathrm{BLH}+a_{6} \cdot T$ & 0.97 \\
\hline
\end{tabular}

pands about $250 \mathrm{~km}$ from east to west (but only about $70 \mathrm{~km}$ from north to south), single air packages ideally may have remained about 4 times longer over the Great Rann for westerly wind conditions in April than during December, which is dominated by wind coming from the north. Aerosol particles that are needed for the bromine explosion mechanism might therefore have an increased probability to be swirled up from the salty surface crust in significant amounts during springtime. An examination of the actual aerosol appearance over the Rann remains, however, difficult, as available satellite aerosol products are strongly influenced by the bright surface of the salt marsh (see also Sect. 3.3).

For the Little Rann of Kutch, the wind direction has a much lower influence on the residence time of the air over the salt marsh, as this part of the salt marsh is much smaller and only slightly extended in an east-west direction $(\approx 50 \times 80 \mathrm{~km})$.

\subsection{Comparison of OMI results with GOME-2 observations}

The GOME-2 instrument overpasses the Rann of Kutch at about 09:30 LT (and therefore $4 \mathrm{~h}$ before OMI). To investigate the diurnal evolution of BrO VCDs over the Rann area, 5 years of GOME-2 data (2007-2011) were evaluated for $\mathrm{BrO}$ in a similar way as for OMI (see Sect. 3 for details). As mentioned in Sect. 3.1, no cloud filter could be applied without losing a significant number of probably cloud-free GOME-2 observations because the operational cloud products mistake the bright surface for clouds. Therefore, only a qualitative seasonal intercomparison of the data will be presented in the following: no cloud filter is used and consequently, a geometrical AMF is used to calculate BrO VCDs (i.e. the data are only corrected for the viewing geometry; explicit radiative transfer calculations are not involved). Please note that the geometrical AMF is this time also applied to OMI data to guarantee the consistency of both data sets. Because fully cloudy cases are not filtered out, low BrO VCDs are not only due to small near-surface $\mathrm{BrO}$ concentrations but also to cloud shielding (possibly even outside of the monsoon season). However, it should be noted that most days outside the monsoon months (June-September) are only effected by low cloud fractions according to MODIS and ECMWF data. In addition, no differences in cloud cover were found that could be attributed to the different overflight time of the instruments throughout the year.

As can be seen from Fig. 9 (lower panel), the seasonal mean BrO VCD maps only indicate a very low enhancement over the salt marsh, which is close to background noise level. Please note that the GOME-2 BrO VCDs are presented using the same colour bar as the corresponding OMI results (Fig. 9, upper panel) to emphasize the low levels of the GOME-2 BrO VCDs. During the monsoon season (here July-September, Fig. 9, lowermost left panel), neither satellite instrument detects a clear enhancement, as massive cloud coverage shields the salt marsh area, but whereas OMI data clearly show a seasonal cycle with a pronounced maximum in April-June, no obvious seasonal variation can be seen in the GOME-2 data. One explanation for the very small $\mathrm{BrO}$ VCDs measured by GOME-2 (compared to OMI) may be differences in chemistry due to different ambient conditions at the early overpass time of GOME-2 (see below). Furthermore, the weak BrO VCD enhancement in the GOME-2 data could at least be partly caused by radiative transfer effects due to the increased surface albedo of the salt marsh. However, as the surface albedo shows a typical seasonal variation in contrast to the GOME-2 BrO VCDs (see Fig. 4), this effect seems to be rather small. While radiative transfer simulations suggest a possible overestimation of the BrO VCDs by a factor of $1.5(50 \%)$ due to an inadequate consideration of the bright surface (Sect. 3.3), this effect can be neglected for OMI, where peak BrO VCDs over the Rann are up to a factor of 16 larger than for areas outside the Rann at low surface albedo.

In principle, there are several instrumental and chemical reasons why the BrO VCDs over the Rann of Kutch derived from GOME-2 are lower than those from OMI: 

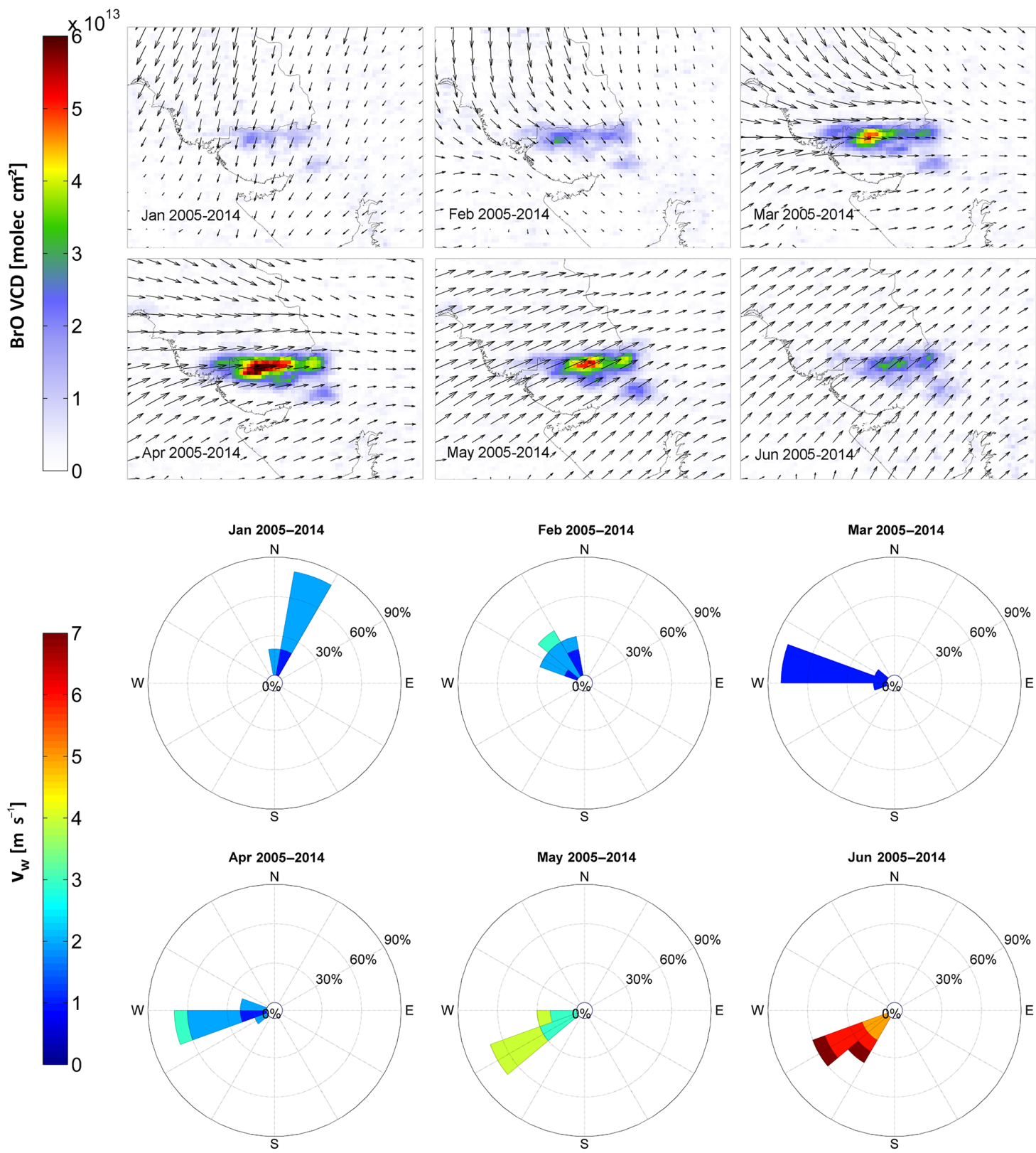

Figure 7. Mean wind field at $10 \mathrm{~m}$ altitude over the Rann of Kutch for the time around the OMI overpass (09:00 UTC) during JanuaryJune 2005-2014 according to ECMWF data together with the BrO VCDs observed from OMI (upper panel). The area is mainly affected by westerly winds at times when BrO VCDs are high. A shift in the BrO distribution in May can be explained by a turning of the main wind direction (and increasing velocity) towards northeast. Corresponding wind speeds (lower panels) are rather low (1-3 $\mathrm{m} \mathrm{s}^{-1}$ ) before they increase with the onset of the monsoon season $\left(>7 \mathrm{~ms}^{-1}\right)$.

1. The spatial resolution of the GOME-2 instrument is $40 \times 80 \mathrm{~km}^{2}$, while the near-nadir ground pixel size of OMI is $13 \times 24 \mathrm{~km}^{2}$. GOME-2 spectra are therefore generally expected to be less sensitive to localized emission sources, as larger ground pixels include a larger fraction of sunlight from areas outside the investigated object (the typical extent of the salt marsh area show- ing clearly enhanced $\mathrm{BrO} \mathrm{VCDs}$ is less than that of a GOME-2 ground pixel).

2. GOME-2 is known to suffer from instrumental degradation (especially in the UV wavelength region) starting in 2008/2009 (Dikty and Richter, 2012). A significant increase in the scatter of retrieved VCDs has been observed, particularly for BrO. This, in addition to the 

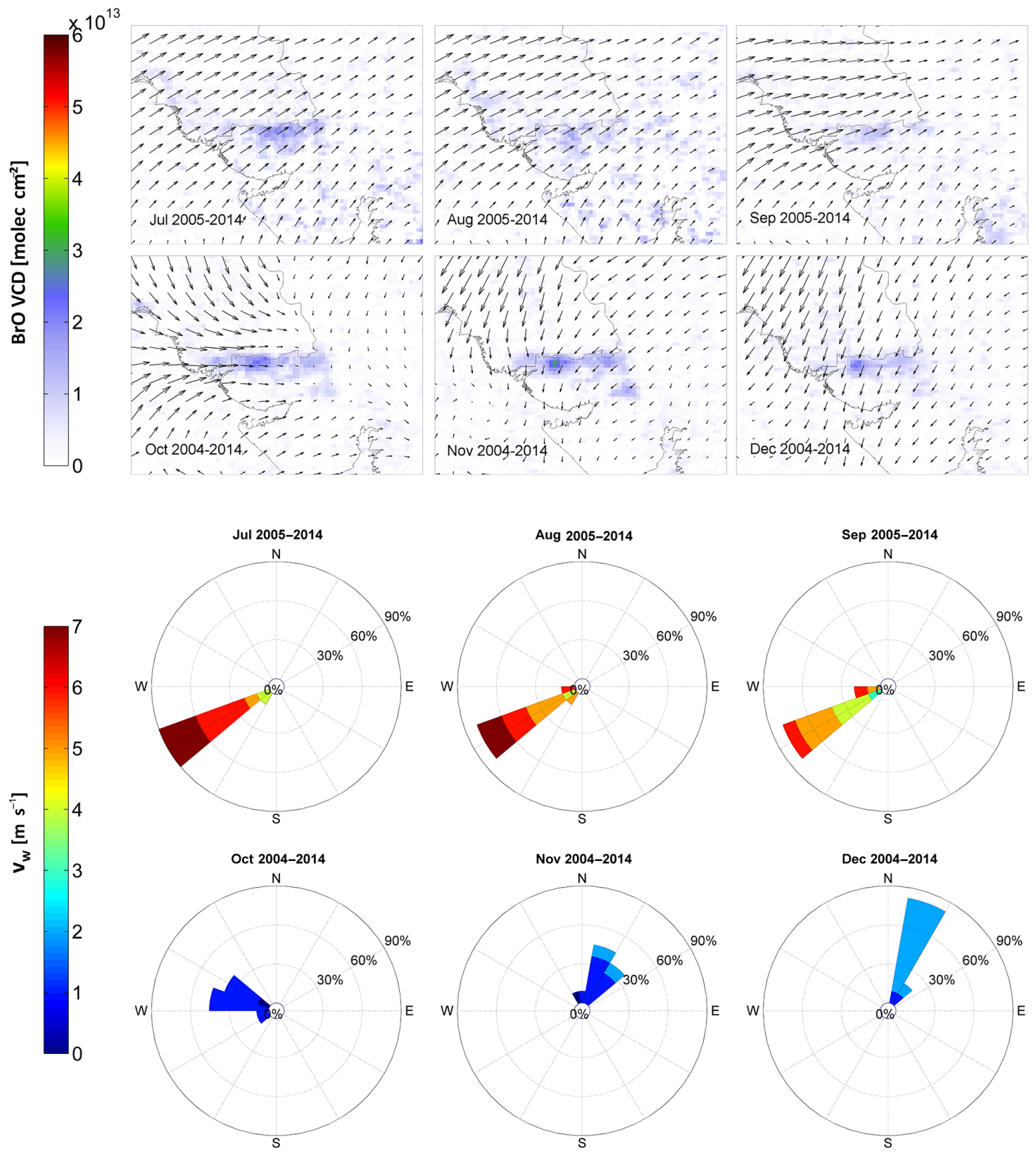

Figure 8. Same as in Fig. 7, but for July to December 2004-2014. The area is mainly affected by strong southwestern winds during monsoon months $\left(>7 \mathrm{~m} \mathrm{~s}^{-1}\right)$. After the monsoon, the wind speed drops rapidly $\left(\approx 2 \mathrm{~m} \mathrm{~s}^{-1}\right)$, and the wind direction changes from west $($ October) to northeast during wintertime.

generally low signal-to-noise ratio of GOME-2 in the UV compared to OMI (Fioletov et al., 2013), has led to a lower sensitivity of the instrument to small $\mathrm{BrO}$ concentrations.

3. One of the main chemical reasons for much lower $\mathrm{BrO}$ VCDs using GOME-2 might be that the measurements take place about $4 \mathrm{~h}$ earlier when compared to OMI observations $(\approx 09: 30$ vs. $13: 30 \mathrm{LT})$. At the time of the morning overpass, the bromine explosion mechanism has presumably not progressed very far, as solar irradiance is approximately $50 \%$ less than during OMI's afternoon overpass (according to ECMWF data) and the process is photolytically driven. Furthermore, $\mathrm{O}_{3}$ is needed for the rapid build-up of $\mathrm{BrO}$, which might be more easily available during the morning on the one hand but may lead to differences in the spatial BrO distribution patterns for GOME-2 when compared to OMI on the other hand. Observations at other salt lakes have 


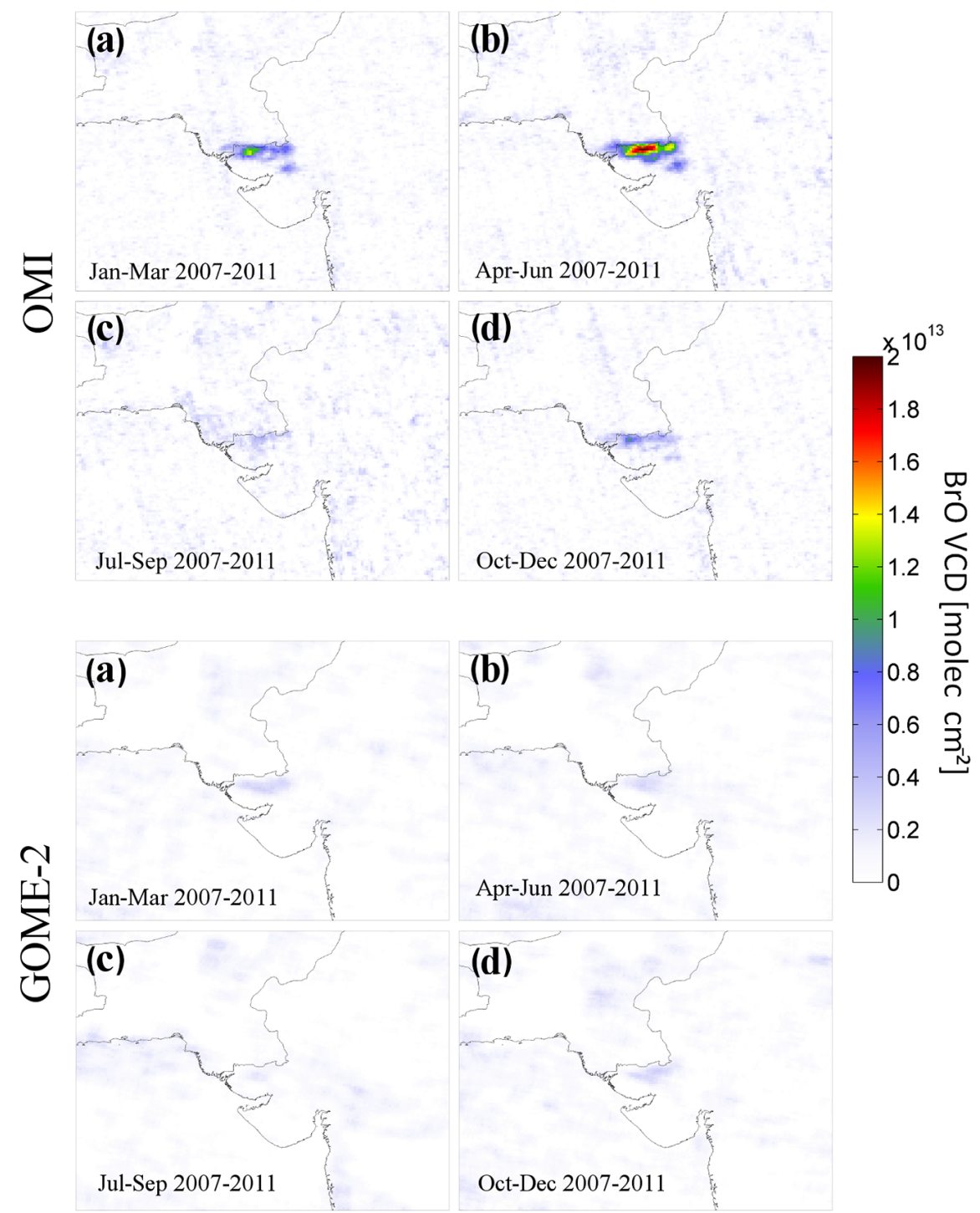

Figure 9. Seasonal mean BrO VCDs over the Rann of Kutch area for OMI (upper panel) and GOME-2 (lower panel) in 2007-2011: (a) January-March, (b) April-June, (c) July-September, (d) October-December. Even for the largest BrO VCDs as seen by OMI during April-June, the GOME-2 VCDs are close to the detection limit and might be at least partly explained by retrieval artefacts caused by the bright surface. Note that, in contrast to Fig. 3, no cloud filter was applied (see text)

shown that the largest BrO VCDs can be expected close to noontime (e.g. Holla et al., 2015).

4. The boundary layer height during the GOME-2 overflight in April and May is significantly lower $(\approx 2 \mathrm{~km})$ than for the OMI measurements $(\approx 3 \mathrm{~km})$. As the $\mathrm{BLH}$ increases towards noon, $\mathrm{BrO}$ originating from the ground might be transported to higher altitudes where it could be more easily detected by the OMI as the instrument's sensitivity generally increases for elevated layers. Additionally, the increasing BLH might lead to an increased mixing-in of tropospheric $\mathrm{O}_{3}$ from higher altitudes and thereby lead to further formation of $\mathrm{BrO}$.
5. Other meteorological parameters (like relative humidity) are expected to influence the efficiency of the bromine explosion (Buxmann et al., 2012). While surface temperature (and associated parameters, e.g. boundary layer height) are lower during the GOME-2 overflight, relative humidity is about $30 \%$ higher. However, the detailed role of meteorological conditions in the bromine explosion mechanism remains unclear (see Sect. 4.3).

Although all of these effects probably contribute to the observed differences between OMI and GOME-2 observations, the reasons for these discrepancies are still a matter of further research. 


\subsection{The Dead Sea (Israel/Jordan)}

OMI data were additionally analysed over another salt lake, the Dead Sea, but the results will only be shortly discussed in the following. A more detailed analysis of the data (or for further locations) exceeds the scope of this paper.

As already mentioned in Sect. 1.1, BrO over the Dead Sea has been frequently observed by ground-based DOAS measurements during recent years. While the results of Hebestreit et al. (1999) suggested that the salt pans over the southern part of the Dead Sea are the main source of the observed BrO, Matveev et al. (2001) and Tas et al. (2005) concluded that $\mathrm{BrO}$ is produced over all parts of the sea, although the frequency and intensity of $\mathrm{BrO}$ production seemed to be more intense over the southern basin. Figure 10 shows the mean $\mathrm{BrO} \mathrm{VCDs}$ for summer months with relatively low cloud coverage (April-October) for the complete data set from 2005 to 2014, including an additional cloud filter of $<30 \%$. As it can be seen from the map, the mean BrO VCDs are clearly enhanced over the southern part of the Dead Sea, while only weakly enhanced VCDs can be identified over the northern part. The results seem to confirm the ground-based findings, although the maximum $\mathrm{BrO} \mathrm{VCDs}$ are shifted towards the southwestern inland, probably because of northeasterly winds that predominate in this area (Matveev et al., 2001). While the Rann of Kutch shows specifically high BrO VCDs in OMI mean maps (at least during April and May), $\mathrm{BrO}$ from other salt lakes like the Dead Sea may generally not be identified as easily from the OMI data for several reasons. Besides lower BrO concentrations, DOAS satellite observations of optically weak absorbers like $\mathrm{BrO}$ are known to suffer from erroneous evaluation results caused by imperfect correction of the Ring effect (Wagner et al., 2009). This effect appears more prominent if the measured scene contains high elevation and bright surfaces like snow-covered mountain ranges (e.g. Salar de Uyuni in the Andes, Chile) in combination with strong cloud coverage during the year. The OMI BrO analysis of individual months over the Dead Sea reveals that the whole Middle East region is indeed more regularly affected by clouded scenes when compared to the Kutch area. Resulting monthly mean maps were hence significantly affected by low statistics. Furthermore, the analysis is complicated by the mountainous areas along the Jordan and Hula Valley and the associated influence on the correction of the Ring effect. In this context it should be noted that significantly enhanced $\mathrm{BrO}$ VCDs were frequently observed north of the Dead Sea valley and close to Tripoli, Libya (not shown). As there is no obvious source for reactive bromine species, to the authors' knowledge, it remains unclear if these findings are caused by residual structures in the DOAS evaluation or actually caused by unknown bromine sources.

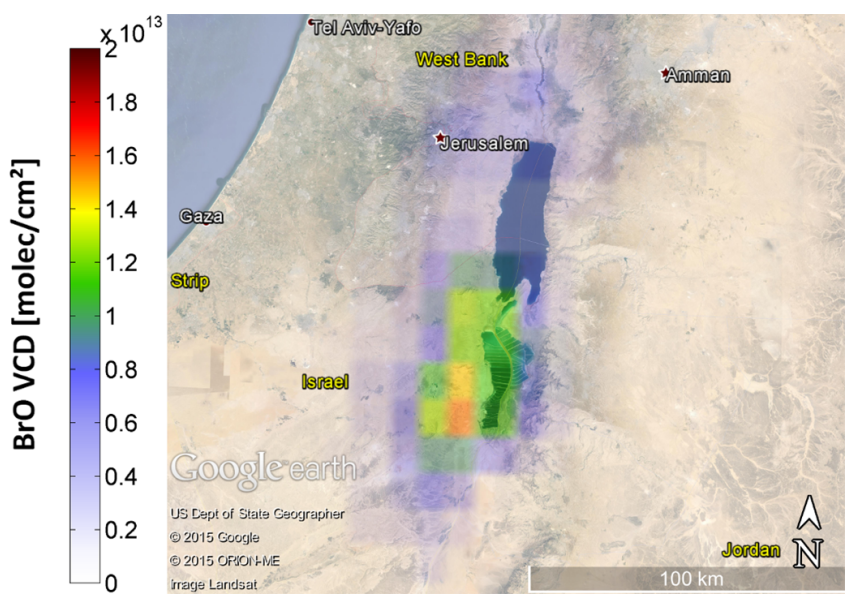

Figure 10. Averaged BrO VCDs over the Dead Sea as seen by OMI during summer months 2005-2014 (April-October). A clear BrO enhancement can be seen over the southern part of the Dead Sea, confirming former ground-based observations by Hebestreit et al. (1999), Matveev et al. (2001) and Tas et al. (2005).

\section{Conclusions}

Satellite measurements have been used to monitor the seasonal cycle of $\mathrm{BrO}$ formation over the Rann of Kutch seasonal salt marsh. In particular, we presented the first space-based measurements of $\mathrm{BrO}$ originating from a salt marsh/salt lake, emphasizing the capability of satellite instruments to monitor remote areas that are only accessible with difficulty for long-term measurements. Up to now, no ground-based atmospheric measurements have been conducted at the Rann of Kutch to the authors' knowledge, despite (or precisely because of) the unique environmental conditions prevailing on-site. The results indicate that the Rann of Kutch salt marsh is probably one of the strongest natural point sources of reactive bromine compounds outside the polar regions and is therefore supposed to have a significant impact on local and regional ozone chemistry.

The OMI measurements reveal a typical annual BrO formation cycle over the Rann, with maximum BrO VCDs appearing during March-May, coinciding with the strongest UV irradiation at the surface. These findings confirm that $\mathrm{BrO}$ is not directly emitted from the surface but driven by photochemistry, which involves the release of $\mathrm{BrO}$ precursors like molecular bromine $\left(\mathrm{Br}_{2}\right)$ as a part of the autocatalytic bromine explosion. During the monsoon (JuneSeptember), the whole Rann of Kutch area is flooded, and a massive decrease in the $\mathrm{BrO}$ VCDs is observed. This effect is, however, partially caused by increased cloud cover, as shielding of the surface strongly affects satellite measurements of trace gases close to the ground. Only slightly enhanced $\mathrm{BrO}$ VCDs show up in wintertime (NovemberFebruary). No clear influence of the Rann's surface albedo can be seen from OMI UV reflectivity measurements. While 
enhanced $\mathrm{BrO}$ VCDs may appear due to an unconsidered increase in the surface albedo, the Rann's surface appears relatively dark during the time of the maximum BrO VCDs (probably because of first moistening towards the monsoon season), and $\mathrm{BrO}$ can hardly be detected during the winter months, when the surface appears brightest.

A first attempt to describe the annual $\mathrm{BrO}$ cycle based on a simple linear parameterization of different meteorological quantities indicates that, in addition to UV irradiation, the variation of the boundary layer height is an essential parameter needed to describe the annual $\mathrm{BrO}$ peak, which can be at least partly explained by the higher sensitivity of the satellite for elevated layers. For an adequate description of the nearsurface $\mathrm{BrO}$ variations, relative humidity and precipitation also play an important role. The seasonal wind conditions can be additionally linked to the observed seasonal variation of the BrO VCDs: the maximum VCDs in March-May are accompanied by westerly winds, which may lead to an increased swirling up of aerosol particles due to the east-west expansion of the Rann and the thereby increased residence time of air masses over the salt crust. In contrast, low VCDs during wintertime are affected by slow winds from the northeast.

Corresponding GOME-2 measurements during the morning (4 $\mathrm{h}$ earlier than $\mathrm{OMI}$ ) show about 4 times lower $\mathrm{BrO}$ VCDs and no clear seasonal cycle, aside from minimum column densities during the strongly cloud-affected monsoon months. Although instrumental reasons may contribute to these findings, the results indicate the fundamental influence of ambient meteorological conditions at the time of the satellite overflight (e.g. the UV radiation at the surface is about $50 \%$ lower) and that the bromine explosion still needs to evolve during the morning hours in order to allow $\mathrm{BrO}$ concentrations to build up to values that may be detected from space.

Additional OMI measurements of enhanced $\mathrm{BrO}$ VCDs over the Dead Sea demonstrate the potential of satellite instruments for the global observation of reactive halogen species over salt lakes. By the improved temporal and in particular spatial resolution of upcoming satellite instruments like the TROPOspheric Monitoring Instrument (TROPOMI, Veefkind et al., 2012, launch expected for early 2017), the number of daily salt lake observations will further increase. Furthermore, satellite instruments on geostationary orbits featuring several measurements per day over the same location like Sentinel-4 (Ingmann et al., 2012, expected for 2019) will allow us to investigate the diurnal evolution of the bromine explosion in more detail (not only over salt lakes). The significantly enhanced $\mathrm{BrO}$ VCDs over the Rann of Kutch in combination with the unique local conditions on the other hand strongly suggest undertaking a ground-based measurement field campaign in that area to better constrain the general release mechanisms of reactive bromine compounds from salt marshes and lakes.

\section{Data availability}

The algorithm has been applied to L1 data from the OMI and GOME-2A satellite instrument. The data are publicly accessible; the respective links to the data sets are included in the references provided in Table 1.

\section{The Supplement related to this article is available online at doi:10.5194/acp-16-13015-2016-supplement.}

Acknowledgements. We would like to thank the agencies providing the satellite data: the OMI OMSO2 (including reflectivity at $331 \mathrm{~nm})$, OMCLDO2 and OMCLDRR products as well as MODIS AQUA/TERRA True Color and channel 7-2-1 images are archived and distributed by the Goddard Earth Sciences Data \& Information Services Center (NASA). We acknowledge EUMETSAT for providing GOME-2A Level 1 data and ECMWF for providing meteorological parameters over India and Pakistan.

The article processing charges for this open-access publication were covered by the Max Planck Society.

Edited by: B. N. Duncan

Reviewed by: two anonymous referees

\section{References}

Acarreta, J. R. and de Haan, J. F.: Cloud Pressure Algorithm Based on $\mathrm{O}_{2}-\mathrm{O}_{2}$ Absorption, chap. 2 in: OMI Algorithm Theoretical Basis Document, Volume III - Clouds, Aerosols, and Surface UV Irradiance, Version 2.0, 17-30, available at: http://eospso.gsfc. nasa.gov/sites/default/files/atbd/ATBD-OMI-03.pdf (last access: 28 January 2016), 2002.

Avallone, L. M.: In situ measurements of bromine oxide at two high-latitude boundary layer sites: Implications of variability, J. Geophys. Res., 108, 4089, doi:10.1029/2002JD002843, 2003.

Barrie, L. A., Bottenheim, J. W., Schnell, R. C., Crutzen, P. J., and Rasmussen, R. A.: Ozone destruction and photochemical reactions at polar sunrise in the lower Arctic atmosphere, Nature, 334, 138-141, doi:10.1038/334138a0, 1988.

Barrie, L. A., den Hartog, G., Bottenheim, J. W., and Landsberger, S.: Anthropogenic aerosols and gases in the lower troposphere at Alert, Canada, in April 1986, J. Atmos. Chem., 9, 101-127, doi:10.1007/BF00052827, 1989.

Begoin, M., Richter, A., Weber, M., Kaleschke, L., Tian-Kunze, X., Stohl, A., Theys, N., and Burrows, J. P.: Satellite observations of long range transport of a large $\mathrm{BrO}$ plume in the Arctic, Atmos. Chem. Phys., 10, 6515-6526, doi:10.5194/acp-10-65152010, 2010.

Bobrowski, N. and Giuffrida, G.: Bromine monoxide / sulphur dioxide ratios in relation to volcanological observations at $\mathrm{Mt}$ Etna 2006-2009, Solid Earth, 3, 433-445, doi:10.5194/se-3-4332012, 2012. 
Bobrowski, N. and Platt, U.: $\mathrm{SO}_{2} / \mathrm{BrO}$ ratios studied in five volcanic plumes, J. Volcanol. Geoth. Res., 166, 147-160, doi:10.1016/j.jvolgeores.2007.07.003, 2007.

Bobrowski, N., Hönninger, G., Galle, B., and Platt, U.: Detection of bromine monoxide in a volcanic plume, Nature, 423, 273-276, doi:10.1038/nature01625, 2003.

Bogumil, K., Orphal, J., Homann, T., Voigt, S., Spietz, P., Fleischmann, O., Vogel, A., Hartmann, M., Kromminga, H., Bovensmann, H., Frerick, J., and Burrows, J.: Measurements of molecular absorption spectra with the SCIAMACHY pre-flight model: instrument characterization and reference data for atmospheric remote-sensing in the $230-2380 \mathrm{~nm}$ region, J. Photochem. Photobio. A, 157, 167-184, doi:10.1016/S1010-6030(03)00062-5, 2003.

Boichu, M., Oppenheimer, C., Roberts, T. J., Tsanev, V., and Kyle, P. R.: On bromine, nitrogen oxides and ozone depletion in the tropospheric plume of Erebus volcano (Antarctica), Atmos. Environ., 45, 3856-3866, doi:10.1016/j.atmosenv.2011.03.027, 2011.

Buxmann, J., Balzer, N., Bleicher, S., Platt, U., and Zetzsch, C.: Observations of bromine explosions in smog chamber experiments above a model salt pan, Int. J. Chem. Kinet., 44, 312-326, doi:10.1002/kin.20714, 2012.

Callies, J., Corpaccioli, E., Eisinger, M., Hahne, A., and Lefevre, A.: GOME-2 - MetOp's Second Generation Sensor for Operational ozone Monitoring, ESA Bulletin, 102, 28-36, 2000.

Carn, S. A., Krotkov, N. A., Yang, K., and Krueger, A. J.: Measuring global volcanic degassing with the Ozone Monitoring Instrument (OMI), Geological Society, London, Special Publications, 380, SP380.12, doi:10.1144/SP380.12, 2013.

Chance, K.: Analysis of BrO measurements from the Global Ozone Monitoring Experiment, Geophys. Res. Lett., 25, 3335-3338, doi:10.1029/98GL52359, 1998.

Chance, K.: OMBRO-OMHCHO-OMOCLO De-Striping README FILE, available at: http://ozoneaq.gsfc.nasa.gov/ media/docs/OMSAO_DeStriping_README.pdf (last access: 28 January 2016), 2007.

Choi, S., Wang, Y., Salawitch, R. J., Canty, T., Joiner, J., Zeng, T., Kurosu, T. P., Chance, K., Richter, A., Huey, L. G., Liao, J., Neuman, J. A., Nowak, J. B., Dibb, J. E., Weinheimer, A. J., Diskin, G., Ryerson, T. B., da Silva, A., Curry, J., Kinnison, D., Tilmes, S., and Levelt, P. F.: Analysis of satellite-derived Arctic tropospheric $\mathrm{BrO}$ columns in conjunction with aircraft measurements during ARCTAS and ARCPAC, Atmos. Chem. Phys., 12, 12551285, doi:10.5194/acp-12-1255-2012, 2012.

Deutschmann, T., Beirle, S., Frieß, U., Grzegorski, M., Kern, C., Kritten, L., Platt, U., Prados-Román, C., Pukite, J., Wagner, T., Werner, B., and Pfeilsticker, K.: The Monte Carlo atmospheric radiative transfer model McArtim: Introduction and validation of Jacobians and 3D features, J. Quant. Spectrosc. Ra., 112, 11191137, doi:10.1016/j.jqstr.2010.12.009, 2011.

Dikty, S. and Richter, A.: GOME-2 on MetOp-A Support for Analysis of GOME-2 In-Orbit Degradation and Impacts on Level 2 Data Products, final report, October 2011, available at: http://www.iup.uni-bremen.de/doas/reports/Final_ Report_Level-2_Data_GOME-2_Degradation.pdf (last access: 28 January 2016), 2012.

EUMETSAT: GOME-2 Product Guide, available at: http: //www.eumetsat.int/website/home/Satellites/CurrentSatellites/
Metop/MetopDesign/GOME2/index.html (last access: 28 January 2016), 2005.

Fioletov, V. E., McLinden, C. A., Krotkov, N., Yang, K., Loyola, D. G., Valks, P., Theys, N., Van Roozendael, M., Nowlan, C. R., Chance, K., Liu, X., Lee, C., and Martin, R. V.: Application of OMI, SCIAMACHY, and GOME-2 satellite $\mathrm{SO}_{2}$ retrievals for detection of large emission sources, J. Geophys. Res.-Atmos., 118, 11399-11418, doi:10.1002/jgrd.50826, 2013.

Frieß, U.: Dynamics and chemistry of tropospheric bromine explosion events in the Antarctic coastal region, J. Geophys. Res., 109, D06305, doi:10.1029/2003JD004133, 2004.

Greenblatt, G. D., Orlando, J. J., Burkholder, J. B., and Ravishankara, A. R.: Absorption Measurements of Oxygen Between 330 and $1140 \mathrm{~nm}$, J. Geophys. Res., 95, 18577-18582, doi:10.1029/JD095iD11p18577, 1997.

Gür, B., Spietz, P., Orphal, J., and Burrows, J. P.: Absorption Spectra Measurements with the GOME-2 FMs using the IUP/IFE-UBs Calibration Apparatus for Trace Gas Absorption Spectroscopy VATGAS, Final Report, University of Bremen, October 2005.

Hausmann, M. and Platt, U.: Spectroscopic measurement of bromine oxide and ozone in the high Arctic during Polar Sunrise Experiment 1992, J. Geophys. Res., 99, 25399-25413, doi:10.1029/94JD01314, 1994.

Hebestreit, K., Stutz, J., Rosen, D., Matveiv, V., Peleg, M., Luria, M., and Platt, U.: DOAS Measurements of Tropospheric Bromine Oxide in Mid-Latitudes, Science, 283, 55-57, doi:10.1126/science.283.5398.55, 1999.

Holla, R.: Reactive Halogen Species above Salt Lakes and Salt Pans, $\mathrm{PhD}$ thesis, University of Heidelberg, available at: http://archiv.ub.uni-heidelberg.de/volltextserver/14636/ 1/Dissertation_Holla_Robert.pdf (last access: 13 October 2016), 2012.

Holla, R., Schmitt, S., Frieß, U., Pöhler, D., Zingler, J., Corsmeier, U., and Platt, U.: Vertical distribution of $\mathrm{BrO}$ in the boundary layer at the Dead Sea, Environ. Chem., 12, 438, doi:10.1071/EN14224, 2015.

Hönninger, G., Bobrowski, N., Palenque, E. R., Torrez, R., and Platt, U.: Reactive bromine and sulfur emissions at Salar de Uyuni, Bolivia, Geophys. Res. Lett., 31, L04101, doi:10.1029/2003GL018818, 2004a.

Hönninger, G., Leser, H., Sebastián, O., and Platt, U.: Ground-based measurements of halogen oxides at the Hudson Bay by active longpath DOAS and passive MAX-DOAS, Geophys. Res. Lett., 31, L04111, doi:10.1029/2003GL018982, 2004b.

Hörmann, C., Sihler, H., Bobrowski, N., Beirle, S., Penning de Vries, M., Platt, U., and Wagner, T.: Systematic investigation of bromine monoxide in volcanic plumes from space by using the GOME-2 instrument, Atmos. Chem. Phys., 13, 4749-4781, doi:10.5194/acp-13-4749-2013, 2013.

Ingmann, P., Veihelmann, B., Straume, A., and Meijer, Y.: The status of implementation of the atmospheric composition related GMES missions Sentinel-4/Sentinel-5 and Sentinel-5p, Proceedings of the 2012 EUMETSAT Meteorological Satellite Conference, Sopot, Poland, 3-7 September 2012.

Joiner, J., Vasilkov, A., Flittner, D., Buscela, E., and Gleason, J.: Retrieval of Cloud Pressure fromn Rotational Raman Scattering, chap. 3 in: OMI Algorithm Theoretical Basis Document, Volume III - Clouds, Aerosols, and Surface UV Irradiance, Version 2.0, 31-46, available at: http://eospso.gsfc.nasa.gov/sites/default/ 
files/atbd/ATBD-OMI-03.pdf (last access: 28 January 2016), 2002.

KNMI: Background information about the Row Anomaly in OMI, available at: http://www.knmi.nl/omi/research/product/ rowanomaly-background.php (last access on 28 January 2016), 2015

Koelemeijer, R. B. A. and Stammes, P.: A fast method for retrieval of cloud parameters using oxygen A band measurements from the Global Ozone Monitoring Experiment, J. Geophys. Res., 106, 3475-3490, doi:10.1029/2000JD900657, 2001.

Koelemeijer, R. B. A., Stammes, P., Hovenier, J. W., and de Haan, J. F.: Global distributions of effective cloud fraction and cloud top pressure derived from oxygen A band spectra measured by the Global Ozone Monitoring Experiment: Comparison to ISCCP data, J. Geophys. Res., 107, AAC 5-1, doi:10.1029/2001JD000840, 2002.

Leser, H., Hönninger, G., and Platt, U.: MAX-DOAS measurements of $\mathrm{BrO}$ and $\mathrm{NO}_{2}$ in the marine boundary layer, Geophys. Res. Lett., 30, 1537, doi:10.1029/2002GL015811, 2003.

Levelt, P. F., van den Oord, G. H. J., Dobber, M. R., Mälkki, A., Visser, H., de Vries, J., Stammes, P., Lundell, J. O. V., and Saari, H.: The Ozone Monitoring Instrument, IEEE Trans. Geosci. Remote Sens., 44, 1093-1101, 2006.

Lieb-Lappen, R. M. and Obbard, R. W.: The role of blowing snow in the activation of bromine over first-year Antarctic sea ice, Atmos. Chem. Phys., 15, 7537-7545, doi:10.5194/acp-15-75372015, 2015.

Loyola R., D. G.: Automatic cloud analysis from polarorbiting satellites using neural network and data fusion techniques, IEEE Geosci. Remote S., 4, 2530-2533, doi:10.1109/IGARSS.2004.1369811, 2004.

Lübcke, P., Bobrowski, N., Arellano, S., Galle, B., Garzón, G., Vogel, L., and Platt, U.: $\mathrm{BrO} / \mathrm{SO}_{2}$ molar ratios from scanning DOAS measurements in the NOVAC network, Solid Earth, 5, 409-424, doi:10.5194/se-5-409-2014, 2014.

Martin, M., Pöhler, D., Seitz, K., Sinreich, R., and Platt, U.: BrO measurements over the Eastern North-Atlantic, Atmos. Chem. Phys., 9, 9545-9554, doi:10.5194/acp-9-9545-2009, 2009.

Matveev, V., Peleg, M., Rosen, D., Tov-Alper, D. S., Hebestreit, K., Stutz, J., Platt, U., Blake, D., and Luria, M.: Bromine oxideozone interaction over the Dead Sea, J. Geophys. Res.-Atmos., 106, 10375-10387, doi:10.1029/2000JD900611, 2001.

Mehta, A. S., Ghosh, P. K., Shah, H. N., and Sanghavi, R. J.: Ideas for process improvement emanating from audit of a bromine plant in the Greater Rann of Kutch, Indian J. Chem. Techn., 10, 644-653, 2003.

Munro, R., Eisinger, M., Anderson, C., Callies, J., Carpaccioli, E., Lang, R., Lefevre, A., Livschitz, Y., and Albinana, A. P.: GOME2 on MetOp, The 2006 EUMETSAT Meteorological Satellite Conference, Helsinki, Finland, 2006.

Oltmans, S. J.: Surface ozone measurements in clean air, J. Geophys. Res., 86, 1174, doi:10.1029/JC086iC02p01174, 1981.

Oltmans, S. J. and Komhyr, W. D.: Surface ozone distributions and variations from 1973-1984: Measurements at the NOAA Geophysical Monitoring for Climatic Change Baseline Observatories, J. Geophys. Res., 91, 5229, doi:10.1029/JD091iD04p05229, 1986.

Oppenheimer, C., Tsanev, V., Braban, C., Cox, R., Adams, J., Aiuppa, A., Bobrowski, N., Delmelle, P., Barclay, J., and Mc- gonigle, A.: BrO formation in volcanic plumes, Geochim. Cosmochim. Ac., 70, 2935-2941, doi:10.1016/j.gca.2006.04.001, 2006.

Pacha, F.: My Name is Salt - a documentary film by Farida Pacha, trigon-film, Ennetbaden, Switzerland, available at: http: //mynameissalt.com (last access: 13 October 2016), 2013.

Peterson, P. K., Simpson, W. R., Pratt, K. A., Shepson, P. B., Frieß, U., Zielcke, J., Platt, U., Walsh, S. J., and Nghiem, S. V.: Dependence of the vertical distribution of bromine monoxide in the lower troposphere on meteorological factors such as wind speed and stability, Atmos. Chem. Phys., 15, 2119-2137, doi:10.5194/acp-15-2119-2015, 2015.

Platt, U. and Janssen, C.: Observation and role of the free radicals $\mathrm{NO}_{3}, \mathrm{ClO}, \mathrm{BrO}$ and $\mathrm{IO}$ in the troposphere, Faraday Discuss., 100, 175-198, doi:10.1039/fd9950000175, 1995.

Platt, U. and Lehrer, E.: Arctic Tropospheric Ozone Chemistry (ARCTOC) - Results from field, laboratory and modelling studies, Final Report of the EU-Project EV5VCT93-0318, available at: http://bookshop.europa.eu/en/ arctic-tropospheric-ozone-chemistry-pbCGNA17783/ (last access: 28 January 2016), 1997.

Platt, U. and Stutz, J.: Differential Optical Absorption Spectroscopy: Principles And Applications, Springer, 2008.

Pöhler, D., Vogel, L., Friess, U., and Platt, U.: Observation of halogen species in the Amundsen Gulf, Arctic, by active long-path differential optical absorption spectroscopy, P. Natl. Acad. Sci. USA, 107, 6582-6587, doi:10.1073/pnas.0912231107, 2010.

Read, K. A., Mahajan, A. S., Carpenter, L. J., Evans, M. J., Faria, B. V. E., Heard, D. E., Hopkins, J. R., Lee, J. D., Moller, S. J., Lewis, A. C., Mendes, L., McQuaid, J. B., Oetjen, H., Saiz-Lopez, A., Pilling, M. J., and Plane, J. M. C.: Extensive halogen-mediated ozone destruction over the tropical Atlantic Ocean, Nature, 453, 1232-1235, doi:10.1038/nature07035, 2008.

Richter, A., Wittrock, F., Eisinger, M., and Burrows, J. P.: GOME observations of tropospheric $\mathrm{BrO}$ in northern hemispheric spring and summer 1997, Geophys. Res. Lett., 25, 26832686, doi:10.1029/98GL52016, 1998.

Rix, M., Valks, P., Hao, N., Loyola, D., Schlager, H., Huntrieser, H., Flemming, J., Koehler, U., Schumann, U., and Inness, A.: Volcanic $\mathrm{SO}_{2}, \mathrm{BrO}$ and plume height estimations using GOME-2 satellite measurements during the eruption of Eyjafjallajökull in May 2010, J. Geophys. Res., 117, D00U19, doi:10.1029/2011JD016718, 2012.

Rozanov, V. V., Kokhanovsky, A. A., Loyola, D., Siddans, R., Latter, B., Stevens, A., and Burrows, J. P.: Intercomparison of cloud top altitudes as derived using GOME and ATSR-2 instruments onboard ERS-2, Remote Sens. Environ., 102, 186-193, doi:10.1016/j.rse.2006.02.009, 2006

Saiz-Lopez, A.: Bromine oxide in the mid-latitude marine boundary layer, Geophys. Res. Lett., 31, L03111, doi:10.1029/2003GL018956, 2004.

Saiz-Lopez, A. and von Glasow, R.: Reactive halogen chemistry in the troposphere, Chem. Soc. Rev., 41, 6448-6472, doi:10.1039/C2CS35208G, 2012.

Salawitch, R. J., Canty, T., Kurosu, T., Chance, K., Liang, Q., da Silva, A., Pawson, S., Nielsen, J. E., Rodriguez, J. M., Bhartia, P. K., Liu, X., Huey, L. G., Liao, J., Stickel, R. E., Tanner, D. J., Dibb, J. E., Simpson, W. R., Donohoue, D., Weinheimer, A., Flocke, F., Knapp, D., Montzka, D., Neuman, J. A., Nowak, 
J. B., Ryerson, T. B., Oltmans, S., Blake, D. R., Atlas, E. L., Kinnison, D. E., Tilmes, S., Pan, L. L., Hendrick, F., Van Roozendael, M., Kreher, K., Johnston, P. V., Gao, R. S., Johnson, B., Bui, T. P., Chen, G., Pierce, R. B., Crawford, J. H., and Jacob, D. J.: A new interpretation of total column $\mathrm{BrO}$ during Arctic spring, Geophys. Res. Lett., 37, L21805, doi:10.1029/2010GL043798, 2010.

Sihler, H., Platt, U., Beirle, S., Marbach, T., Kühl, S., Dörner, S., Verschaeve, J., Frieß, U., Pöhler, D., Vogel, L., Sander, R., and Wagner, T.: Tropospheric BrO column densities in the Arctic derived from satellite: retrieval and comparison to ground-based measurements, Atmos. Meas. Tech., 5, 27792807, doi:10.5194/amt-5-2779-2012, 2012.

Smoydzin, L. and von Glasow, R.: Modelling chemistry over the Dead Sea: bromine and ozone chemistry, Atmos. Chem. Phys., 9, 5057-5072, doi:10.5194/acp-9-5057-2009, 2009.

Stammes, P., Sneep, M., de Haan, J. F., Veefkind, J. P., Wang, P., and Levelt, P. F.: Effective cloud fractions from the Ozone Monitoring Instrument: Theoretical framework and validation, J. Geophys. Res., 113, D16S38, doi:10.1029/2007JD008820, 2008.

Stutz, J., Ackermann, R., Fast, J. D., and Barrie, L.: Atmospheric reactive chlorine and bromine at the Great Salt Lake, Utah, Geophys. Res. Lett., 29, 18-1-18-4, doi:10.1029/2002GL014812, 2002.

Tas, E., Peleg, M., Matveev, V., Zingler, J., and Luria, M.: Frequency and extent of bromine oxide formation over the Dead Sea, J. Geophys. Res.-Atmos., 110, D11304, doi:10.1029/2004JD005665, 2005.

Tas, E., Peleg, M., Pedersen, D. U., Matveev, V., Pour Biazar, A., and Luria, M.: Measurement-based modeling of bromine chemistry in the boundary layer: 1 . Bromine chemistry at the Dead Sea, Atmos. Chem. Phys., 6, 5589-5604, doi:10.5194/acp-65589-2006, 2006.

Theys, N., Roozendael, M. V., Dils, B., Hendrick, F., Hao, N., and Mazière, M. D.: First satellite detection of volcanic bromine monoxide emission after the Kasatochi eruption, Geophys. Res. Lett., 36, L03809, doi:10.1029/2008GL036552, 2009a.

Theys, N., Van Roozendael, M., Errera, Q., Hendrick, F., Daerden, F., Chabrillat, S., Dorf, M., Pfeilsticker, K., Rozanov, A., Lotz, W., Burrows, J. P., Lambert, J.-C., Goutail, F., Roscoe, H. K., and De Mazière, M.: A global stratospheric bromine monoxide climatology based on the BASCOE chemical transport model, Atmos. Chem. Phys., 9, 831-848, doi:10.5194/acp-9-831-2009, 2009b.

Theys, N., Van Roozendael, M., Hendrick, F., Yang, X., De Smedt, I., Richter, A., Begoin, M., Errera, Q., Johnston, P. V., Kreher, K., and De Mazière, M.: Global observations of tropospheric BrO columns using GOME-2 satellite data, Atmos. Chem. Phys., 11, 1791-1811, doi:10.5194/acp-11-1791-2011, 2011.
Theys, N., De Smedt, I., Van Roozendael, M., Froidevaux, L., Clarisse, L., and Hendrick, F.: First satellite detection of volcanic $\mathrm{OClO}$ after the eruption of Puyehue-Cordón Caulle, Geophys. Res. Lett., 41, 667-672, doi:10.1002/2013GL058416, 2014.

Torres, O., Tanskanen, A., Veihelmann, B., Ahn, C., Braak, R., Bhartia, P. K., Veefkind, P., and Levelt, P.: Aerosols and surface UV products from Ozone Monitoring Instrument observations: An overview, J. Geophys. Res., 112, D24S47, doi:10.1029/2007JD008809, 2007.

Vandaele, A. C., Hermans, C., Fally, S., Carleer, M., Colin, R., Mérienne, M., Jenouvrier, A., and Coquart, B.: High-resolution Fourier transform measurement of the $\mathrm{NO}_{2}$ visible and nearinfrared absorption cross sections: Temperature and pressure effects, J. Geophys. Res., 107, 4348, doi:10.1029/2001JD000971, 2002.

Vasilkov, A., Joiner, J., Spurr, R., Bhartia, P. K., Levelt, P., and Stephens, G.: Evaluation of the OMI cloud pressures derived from rotational Raman scattering by comparisons with other satellite data and radiative transfer simulations, J. Geophys. Res., 113, D15S19, doi:10.1029/2007JD008689, 2008.

Veefkind, J. P., Aben, I., McMullan, K., Förster, H., de Vries, J., Otter, G., Claas, J., Eskes, H. J., de Haan, J. F., Kleipool, Q., van Weele, M., Hasekamp, O., Hoogeveen, R., Landgraf, J., Snel, R., Tol, P., Ingmann, P., Voors, R., Kruizinga, B., Vink, R., Visser, H., and Levelt, P. F.: TROPOMI on the ESA Sentinel-5 Precursor: A GMES mission for global observations of the atmospheric composition for climate, air quality and ozone layer applications, Remote Sens. Environ., 120, 70-83, doi:10.1016/j.rse.2011.09.027, 2012.

Wagner, T. and Platt, U.: Satellite mapping of enhanced BrO concentrations in the troposphere, Nature, 395, 486-490, doi:10.1038/26723, 1998.

Wagner, T., Beirle, S., and Deutschmann, T.: Three-dimensional simulation of the Ring effect in observations of scattered sun light using Monte Carlo radiative transfer models, Atmos. Meas. Tech., 2, 113-124, doi:10.5194/amt-2-113-2009, 2009.

Wilmouth, D. M., Hanisco, T. F., Donahue, N. M., and Anderson, J. G.: Fourier Transform Ultraviolet Spectroscopy of the $\mathrm{A}^{2} \Pi_{3 / 2}$ $\leftarrow X^{2} \Pi_{3 / 2}$ Transition of BrO, J. Phys. Chem. A, 103, 89358945, doi:10.1021/jp991651o, 1999. 